\title{
Viburnum opulus L. Juice Phenolic Compounds Influence Osteogenic Differentiation in Human Osteosarcoma Saos-2 Cells
}

\author{
Małgorzata Zakłos-Szyda ${ }^{1, * \mathbb{D}}$, Adriana Nowak ${ }^{2} \mathbb{D}$, Nina Pietrzyk ${ }^{1}\left(\mathbb{D}\right.$ and Anna Podsędek ${ }^{1}(\mathbb{D}$ \\ 1 Institute of Molecular and Industrial Biotechnology, Department of Biotechnology and Food Sciences, \\ Lodz University of Technology, Stefanowskiego 4/10, 90-924 Łódź, Poland; \\ nina.pietrzyk@dokt.p.lodz.pl (N.P.); anna.podsedek@p.lodz.pl (A.P.) \\ 2 Department of Environmental Biotechnology, Lodz University of Technology, Wólczańska 171/173, \\ 90-924 Łódź, Poland; adriana.nowak@p.lodz.pl \\ * Correspondence: malgorzata.zaklos-szyda@p.lodz.pl
}

Received: 14 June 2020; Accepted: 10 July 2020; Published: 11 July 2020

\begin{abstract}
Bone mass loss occurs with a decrease in osteoblast proliferation and differentiation, or the enhancement of bone resorption, which further leads to the impairment of bone mineral density and increase in bone fracture. Recent studies suggest that some phenolic compounds found in food play positive role in bone metabolism. High content of phenolic compounds with potential beneficial effects on bone metabolism have been identified in the Viburnum opulus fruit. The aim of the study was to determine the influence of $V$. opulus fresh juice (FJ) and juice purified by solid phase extraction (PJ) on osteogenesis processes with osteosarcoma Saos-2 cell lines. V. opulus purified juice revealed stronger potential as an inducer of Saos-2 osteogenic differentiation. Saos-2 cells matrix mineralization was evaluated with alkaline phosphatase (ALP) activity measurement and alizarin red S staining. Gene expression analysis showed the elevation of the mRNA levels of Runt-related transcription factor 2 (RUNX2), ALP, collagen type 1 and osteonectin, whereas the nuclear factor-kB ligand and osteoprotegerin ratio (RANKL/OPG) decreased. Furthermore, V. opulus was able to diminish the secretion of pro-inflammatory cytokines $\mathrm{Il} 6$ and $\mathrm{TNF} \alpha$, however had no effect on vascular endothelial growth factor (VEGF). It decreased intracellular oxidative stress and induced DNA repair, but had no effect on the growth inhibition of lactic acid beneficial microorganisms.
\end{abstract}

Keywords: Viburnum opulus; phenolic compounds; Saos-2

\section{Introduction}

Homeostasis between bone resorption and bone formation maintains bone tissue integrity and health, and is controlled both by physical stimulation and cellular signaling molecules [1,2]. The osteoclasts reducing the mineralized extracellular matrix and the osteoblasts producing organic bone are mainly involved in bone architecture modelling [3]. In osteoporosis, the reduction in osteogenesis occurs with an enhancement of bone resorption, leading to the impairment of bone mineral density and increase in bone fractures [4]. The major osteogenesis regulation factor is Runt-related transcription factor 2 (RUNX2), which regulates the proliferation of osteoblast progenitors and their differentiation into osteoblasts [5]. Differentiated osteoblasts are characterized by the increase in alkaline phosphatase (ALP) activity and increased expressions of bone markers, such as type I collagen (COL1A1), helping in mineral deposition, or osteonectin binding selectively to both hydroxyapatite and collagen 1 , improving its mineralization [6]. At the cellular level, stimulation of osteoclasts is correlated with the upregulation of inflammatory cytokines, including interleukin 1 (Il1), interleukin 6 (Il6) and tumor necrosis factor $\alpha(\mathrm{TNF} \alpha)$ [7]. The other mechanisms leading to osteoclast activation and maturation 
involve signal transduction after the receptor activator of the nuclear factor- $\mathrm{KB}$ ligand (RANKL) binding with its RANK receptor, expressed by osteoclasts. The osteoprotegerin (OPG) secreted by osteoblasts captures RANKL, which limits its binding to the RANK receptor and, in turn, sustains bone mass. Due to the significant impact on morbidity, osteoporosis has been included in the most world-wide relevant nutrition-related chronic diseases, along with cancer, diabetes, obesity and cardiovascular diseases [4]. Whereas the etiology of osteoporosis is very complex, recent data link bone loss with the obesity state. Obesity-related enhanced adipocyte growth leads to the elevation of proinflammatory cytokine production, and thus intensifies osteoclast differentiation via RANKL/RANK/OPG signal transduction and, finally, bone resorption [8-11]. In the prevention and treatment of osteoporosis, there are used estrogens or selective estrogen receptor modulators; however, due to the side effects resulting from their prolonged usage, less harmful plant derived substitutes are being searched [12].

Epidemiological studies correlated a diet enriched in fruits and vegetables with a lowered risk of chronic disease development [13]. Its beneficial role for human health is mainly associated with the consumption of polyphenols [14-19]. These secondary plant metabolites' protective role might be linked to antioxidant and anti-inflammatory properties; however, there is growing evidence about their direct influence on gene expression. Growing data reveal that phenolic compounds, especially tea catechins, procyanidins and chlorogenic acids, have a beneficial impact on restraining osteoporosis induced by oxidative-stress, as well as bone loss during a high-fat diet [1,20-23]. What is more, a recent study demonstrated that, in obese children treated with sweet cherry polyphenols, the osteoclastogenesis process was decreased, as well as the level of TNF $\alpha$ [10].

Our previous studies identified Viburnum opulus fruit as a rich source of phenolic compounds, with chlorogenic acid, proanthocyanidins and catechins as the main constituents, as shown in Figure 1 [24,25]. Despite their high antioxidant potential, V. opulus phenolics were able to decrease intracellular oxidative stress and inhibit cell migration [24-26]. Further studies revealed that V. opulus was involved in lipid and carbohydrate metabolism regulation in human epithelial Caco-2 and mice insulinoma MIN6 cells, where the alteration of selected gene expression was observed. Taking into account a significant impact of $V$. opulus phenolic compounds on the modulation of cellular metabolism, as well as its phenolic compounds composition, in the present study we investigated the effect of $V$. opulus fruit juice on the metabolic activity and mineralization process in human osteosarcoma Saos-2 cell lines. Saos-2 cells display osteoblastic features similar to primary human osteoblastic cells-they express active alkaline phosphatase and form the calcified matrix [27]. The presented studies assessed V. opulus juice's influence on the activity of alkaline phosphatase and matrix mineralization, as well as the expression of genes related to osteogenic differentiation (RUNX2, RANKL, OPG, osteonectin, ALP, TNF $\alpha$, Il6). Furthermore, the influence of $V$. opulus components on vascular endothelial growth factor (VEGF) secretion by human umbilical vein endothelial cells (HUVEC) was elucidated.

The symbiosis between gut microbiota and the host requires a homeostasis, which, once disrupted, may increase the risk of osteoporosis. The imbalance in the human gut microbiota can lead to the release of active compounds that contribute to multiple organ dysfunctions. Furthermore, in view of the fact that gut microbiota can play a significant role in osteoporosis, the antimicrobial activity of $V$. opulus juice phenolics towards selected pathogens, contributing to inflammation in the human body, was estimated. Additionally, the inhibitory effect of V. opulus on beneficial Lactobacillus sp. strains was evaluated 


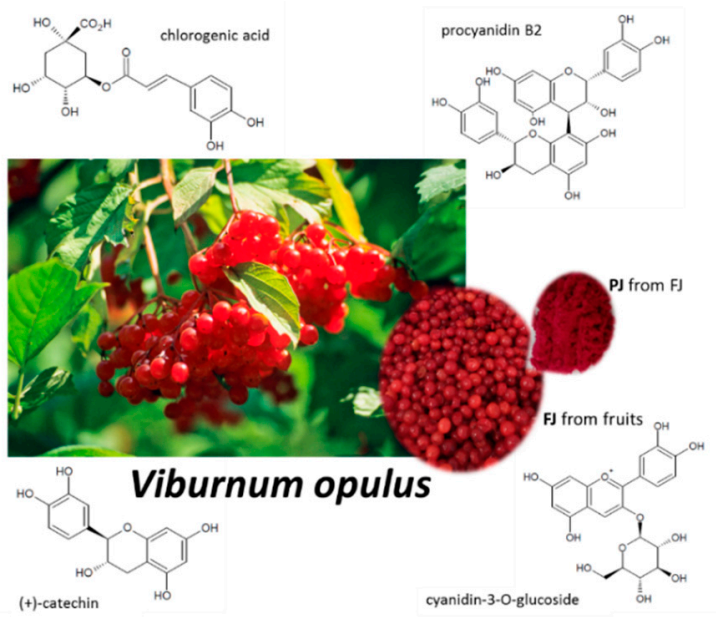

Figure 1. Viburnum opulus fruit as source of fresh juice (FJ) and purified juice (PJ); structures of the main phenolic compounds identified in $V$. opulus samples.

V. opulus fruits are used in food products, such as herbal tea, juice, cordials and liqueurs, fermented drinks, jams, marmalades and sauces [28]. However, due to the fruit's bitterness and astringent properties, the obtained fresh juice has a very specific taste and needs to be diluted before consumption. Therefore, the effective concentration of V. opulus phenolics can be difficult to achieve in the gut. What is more, a much lower concentration of phenolic compounds present in fresh juice would require the consumption of increased amounts of juice. Solid phase extraction turned out to be a very effective method of increasing the concentration of phenolic compounds in the final formulation. The resulting purified juice (PJ) preparation, obtained from fresh juice (FJ), can be a component of functional food for people with osteoporosis. That preparation can also be used to check the direct interaction of the $V$. opulus phenolic components with other isoflavones, which are present in many pharmaceuticals intended for menopausal women. Thus, in the present study we investigated $V$. opulus fruit fresh juice (FJ) and purified juice (PJ) effects on the Saos-2 cells mineralization process.

\section{Results}

\subsection{Content of Phenolic Compounds in Fresh and Purified Juices of Viburnum opulus Fruit}

Individual phenolic compounds' contents are presented in Table 1. Their identification, based on retention times, wavelengths of maximum absorbance, deprotonated molecules $\left([\mathrm{M}-\mathrm{H}]^{-}\right)$and diagnostic fragments (MS/MS) was described in our previous paper [29]. The total phenolic contents were $11.508 \pm 0.154 \mathrm{mg} / \mathrm{g}$ freeze-dried fresh juice (FJ) and $878.632 \pm 2.722 \mathrm{mg} / \mathrm{g}$ freeze-dried purified juice (PJ). The FJ and PJ showed the presence of different groups of phenolic compounds, such as hydroxycinnamic acids, flavanols, flavonols- and anthocyanins. The mentioned groups of phenolic compounds participated with 77.50, 19.52, 0.37 and $2.61 \%$ of the total phenolic in FJ, and with 80.46, $16.30,0.32$ and $2.92 \%$ in PJ, respectively. Significant differences $(p \leq 0.05)$ in the contents of individual phenolic compounds between FJ and PJ were noted as a result of about a 90-fold increase in the content of phenolics in PJ. Chlorogenic acid showed the highest content, both among phenolic compounds and hydroxycinnamic acids. Its concentrations were $645.492 \pm 1.984 \mathrm{mg} / \mathrm{g}$ and $8.039 \pm 0.145 \mathrm{mg} / \mathrm{g}$ in PJ and FJ, respectively. Procyanidin dimer B1 and (+)-catechin were quantitatively dominant polyphenols in the flavanol group. In the tested FJ and PJ, cyanidin-3-glucoside and quercetin-3-vicianoside were the main anthocyanin and flavanol, respectively. 


\subsection{V. opulus Influence on Cellular Metabolic Activity and Proliferation}

To understand the impact of $V$. opulus on Saos-2 cells we first compared the influence of fresh juice and purified juice on mitochondrial enzyme activity with Presto Blue reagent.

After reaching confluence, the cells were incubated for $48 \mathrm{~h}$ with $V$. opulus samples increasing in concentration from 10 to $200 \mu \mathrm{g} / \mathrm{mL}$. The results in Figure 2A show that at the highest dosage FJ decreased metabolic activity by almost $45 \%$. No cytotoxic effect on Saos- 2 cells was observed for the FJ concentration up to $100 \mu \mathrm{g} / \mathrm{mL}$. At the same time, the PJ revealed higher cytotoxic potential than fresh juice, with the highest non-cytotoxic concentration equal to $50 \mu \mathrm{g} / \mathrm{mL}$, as shown in Figure 2B. Cell incubation with $200 \mu \mathrm{g} / \mathrm{mL}$ PJ revealed the cell metabolic activity decreased by almost $90 \%$.

Table 1. Phenolic compound contents in fresh juice and purified juice of Viburnum opulus fruit.

\begin{tabular}{|c|c|c|c|}
\hline \multirow{2}{*}{\multicolumn{2}{|c|}{ Phenolic Compound }} & \multicolumn{2}{|c|}{ Content (mg/g) } \\
\hline & & Fresh Juice (FJ) & Purified Juice (PJ) \\
\hline \multirow{14}{*}{ FLAVANOLS } & $(+)$-Catechin & $0.657 \pm 0.006$ & $40.729 \pm 0.596$ \\
\hline & (-)-Epicatechin & $0.135 \pm 0.002$ & $8.002 \pm 0.116$ \\
\hline & (Epi)catechin derivative $\mathrm{I}^{\mathrm{a}}$ & $0.103 \pm 0.001$ & $6.998 \pm 0.221$ \\
\hline & (Epi)catechin derivative II $^{\mathrm{a}}$ & $0.080 \pm 0.001$ & $6.006 \pm 0.165$ \\
\hline & Gallocatechin gallate ${ }^{\mathrm{a}}$ & $0.031 \pm 0.000$ & $1.876 \pm 0.085$ \\
\hline & Procyanidin dimer B1 & $0.759 \pm 0.003$ & $47.596 \pm 0.148$ \\
\hline & Procyanidin dimer B2 & $0.199 \pm 0.002$ & $11.540 \pm 0.148$ \\
\hline & Procyanidin dimer ${ }^{b}$ & $0.024 \pm 0.001$ & $1.602 \pm 0.258$ \\
\hline & $\begin{array}{l}\text { B-type procyanidin dimer } \\
\text { derivative } \mathrm{I}^{\mathrm{b}}\end{array}$ & $0.016 \pm 0.000$ & $2.071 \pm 0.097$ \\
\hline & $\begin{array}{l}\text { B-type procyanidin dimer } \\
{\text { derivative } \text { II }^{\mathrm{b}}}\end{array}$ & $0.035 \pm 0.000$ & $2.293 \pm 0.094$ \\
\hline & Procyanidin trimer $\mathrm{C} 1$ & $0.033 \pm 0.001$ & $3.212 \pm 0.351$ \\
\hline & Procyanidin trimer $\mathrm{I}^{\mathrm{c}}$ & $0.112 \pm 0.001$ & $6.866 \pm 0.342$ \\
\hline & Procyanidin trimer $\mathrm{II}^{\mathrm{c}}$ & $0.030 \pm 0.006$ & $2.634 \pm 0.270$ \\
\hline & Procyanidin trimer III ${ }^{\mathrm{c}}$ & $0.032 \pm 0.000$ & $1.796 \pm 0.053$ \\
\hline \multirow{11}{*}{ HYDROXYCINNAMIC ACIDS } & Chlorogenic acid & $8.039 \pm 0.145$ & $645.492 \pm 1.984$ \\
\hline & Cryptochlorogenic acid & $0.004 \pm 0.000$ & $0.484 \pm 0.023$ \\
\hline & Neochlorogenic acid & $0.007 \pm 0.001$ & $0,215 \pm 0.019$ \\
\hline & Caffeoylquinic acid ${ }^{\mathrm{d}}$ & $0.745 \pm 0.001$ & $44.344 \pm 0.176$ \\
\hline & Caffeoylquinic acid derivative $\mathrm{I}^{\mathrm{d}}$ & $0.015 \pm 0.000$ & $1.289 \pm 0.058$ \\
\hline & Caffeoylquinic acid derivative $\mathrm{II}^{\mathrm{d}}$ & $0.024 \pm 0.002$ & $1.051 \pm 0.008$ \\
\hline & Caffeoylquinic acid derivative $\mathrm{III}^{\mathrm{d}}$ & $0.017 \pm 0.001$ & $1.220 \pm 0.020$ \\
\hline & Caffeoylquinic acid derivative IV $^{\mathrm{d}}$ & $0.034 \pm 0.000$ & $3.306 \pm 0.014$ \\
\hline & Caffeoylquinic acid derivative $\mathrm{V}^{\mathrm{d}}$ & $0.034 \pm 0.000$ & $3.268 \pm 0.010$ \\
\hline & Feruloylquinic acid I $\mathrm{I}^{\mathrm{d}}$ & n.d. & $5.722 \pm 0.021$ \\
\hline & Feruloylquinic acid $\mathrm{II}^{\mathrm{d}}$ & n.d. & $0.528 \pm 0.005$ \\
\hline \multirow{4}{*}{ FLAVONOLS } & Quercetin-3-vicianoside ${ }^{\mathrm{e}}$ & $0.020 \pm 0.000$ & $1.266 \pm 0.007$ \\
\hline & Quercetin-3-galactoside ${ }^{\mathrm{e}}$ & n.d. & $0.149 \pm 0.011$ \\
\hline & Quercetin-3-rutinoside & $0.016 \pm 0.000$ & $0.921 \pm 0.007$ \\
\hline & Quercetin-3-rhamnoside ${ }^{\mathrm{e}}$ & $0.007 \pm 0.000$ & $0.491 \pm 0.002$ \\
\hline \multirow{3}{*}{ ANTHO-CYANINS } & Cyanidin-3-sambubioside & $0.093 \pm 0.000$ & $7.010 \pm 0.003$ \\
\hline & Cyanidin-3-glucoside & $0.139 \pm 0.000$ & $13.583 \pm 0.799$ \\
\hline & Cyanidin-3-rutinoside & $0.068 \pm 0.001$ & $5.246 \pm 0.016$ \\
\hline
\end{tabular}

n.d. - not detected; results are expressed as a mean \pm standard deviation $(n=3)$. Content expressed as: ${ }^{a}$-equivalents of $(+)$-catechin; ${ }^{b}$-equivalents of procyanidin $\mathrm{B} 1{ }^{c}{ }^{c}$ - equivalents of procyanidin $\mathrm{C} 1{ }^{d}{ }^{d}$ - equivalents of chlorogenic acid; ${ }^{\mathrm{e}}$ - equivalents of quercetin 3-glucoside. 

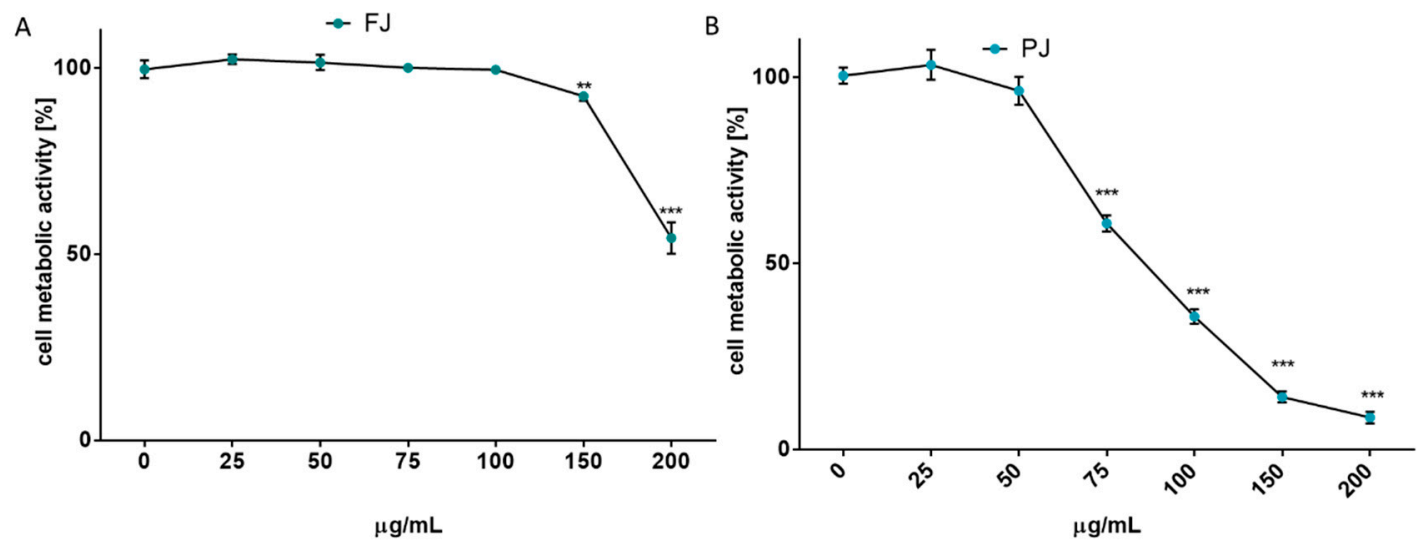

Figure 2. The influence of $V$. opulus on Saos-2 cell metabolic activity, determined by Presto Blue reagent after $48 \mathrm{~h}$ exposure with FJ (A) and PJ (B); control cells were not exposed to any compound; values are means $\pm \mathrm{SEM}, n \geq 12$; statistical significance was calculated versus control cells (untreated), ${ }^{* *} p \leq 0.01$, $* * * \quad 0.001$.

Due to the long incubation of cells with $V$. opulus samples, their influence on cell proliferation was additionally checked with CyQuant Proliferation Assay, which relies on the fluorescence measurement of the cyanine dye bound to cellular nucleic acids. The $V$. opulus samples in the tested concentration range had no stimulatory effect on the proliferation of Saos-2 cells. As is presented in Figure 3A,B, purified juice negatively affected the DNA content at $50 \mu \mathrm{g} / \mathrm{mL}$ doze, decreasing the cell proliferation by $15 \%$, whereas the comparable result of FJ was observed for $150 \mu \mathrm{g} / \mathrm{mL}$ concentration. A comparison of $V$. opulus inhibitory effects on cell proliferation and metabolic activity demonstrated that both samples decreased cell division more efficiently than metabolism, as shown in Figures 2 and 3. Thus, taking into account the obtained results, the highest non-cytotoxic concentrations $\left(\mathrm{IC}_{0}\right)$ chosen for the studies of osteoblast activity regulation were $100 \mu \mathrm{g} / \mathrm{mL}$ of fresh juice and $25 \mu \mathrm{g} / \mathrm{mL}$ of purified juice.
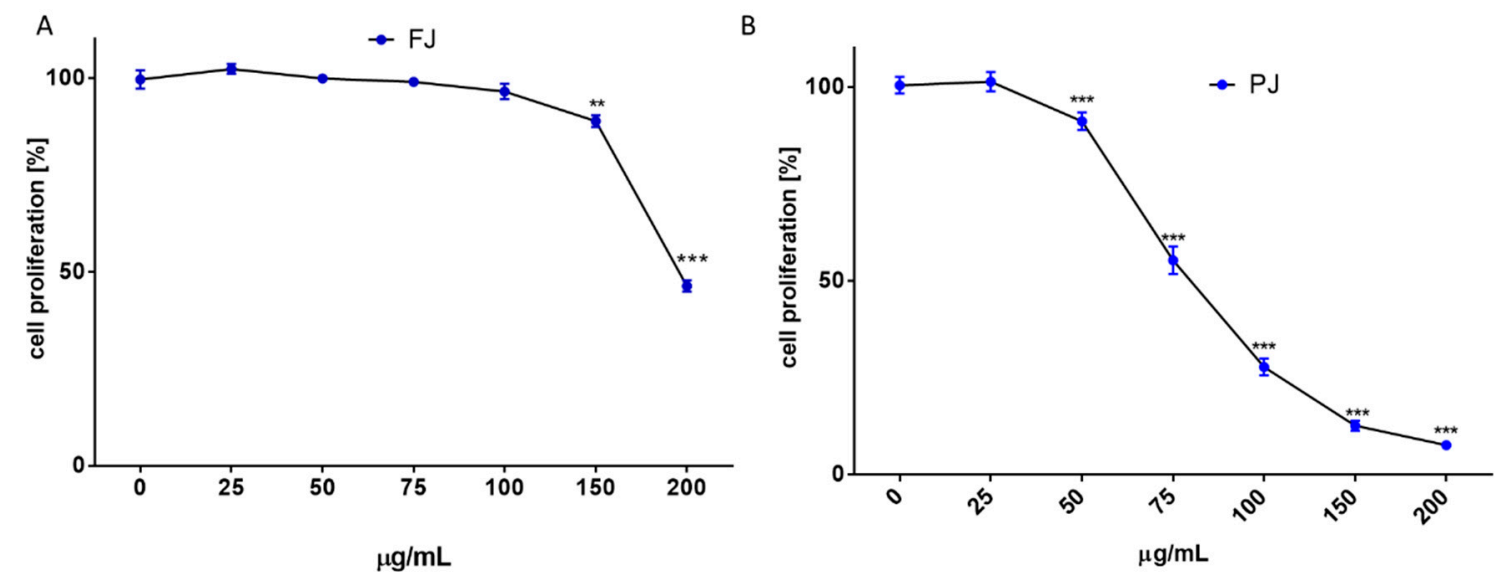

Figure 3. Cont. 

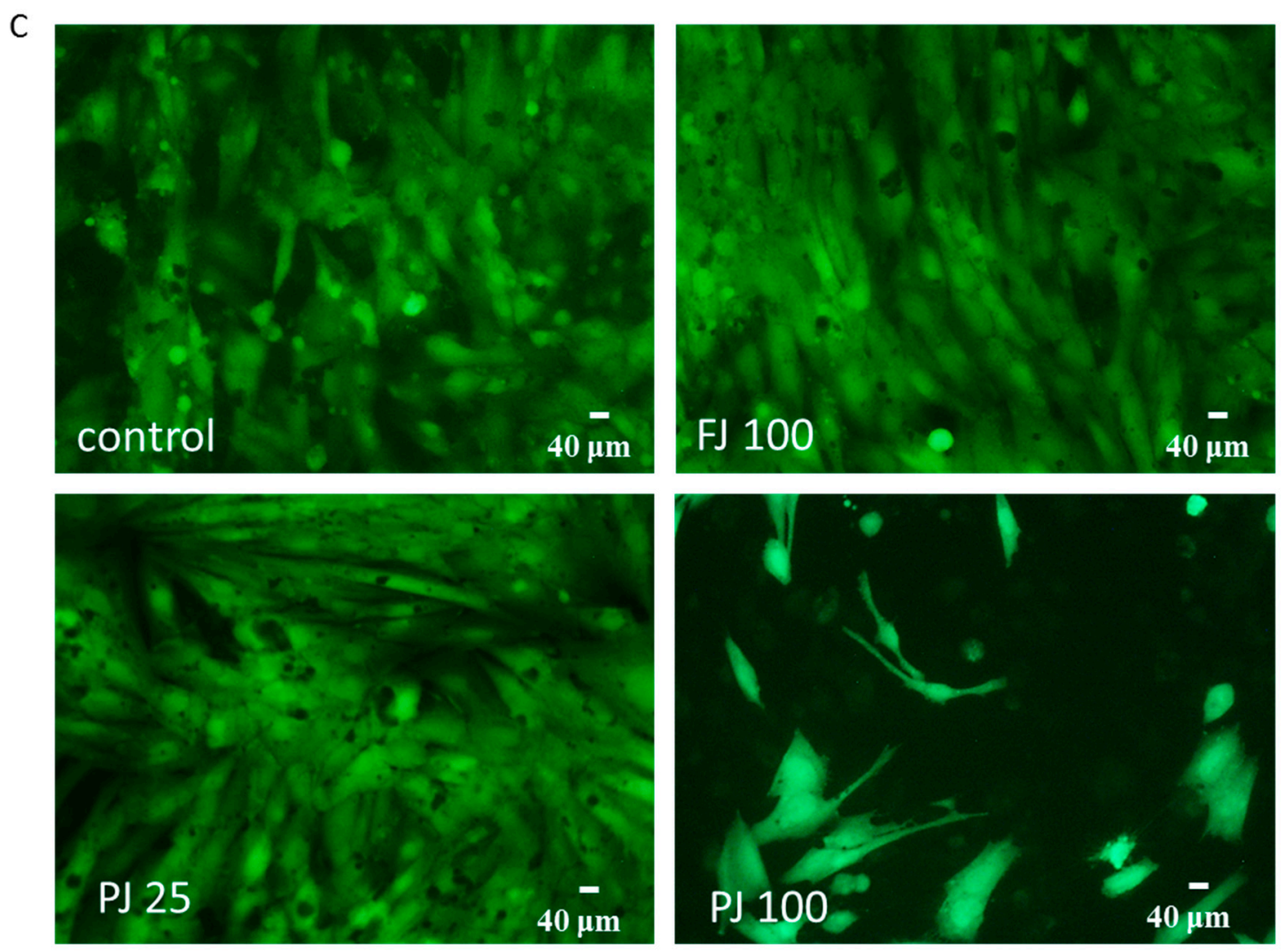

Figure 3. The influence of $V$. opulus on Saos-2 cell proliferation, determined by CyQuant reagent after 48 h exposure with FJ (A) and PJ (B); control cells were not exposed to any compound; values are means \pm SEM, $n \geq 12$; statistical significance was calculated versus control cells (untreated), ${ }^{* *} p \leq 0.01$, *** $p \leq 0.001$. Morphology of Saos- 2 cells stained with $2 \mu \mathrm{M}$ calcein AM observed after incubation with 25 and $100 \mu \mathrm{g} / \mathrm{mL}$ of PJ, and $100 \mu \mathrm{g} / \mathrm{mL}$ of FJ (C); randomly chosen fields were photographed at $\times 400$ with fluorescent microscope.

Microscopic observations performed with calcein AM ester confirmed the lack of cytotoxic effects of V. opulus samples at IC 0 concentration on Saos-2 cells, as shown in Figure 3C. In healthy cells with active esterases, there is a visible strong cytosolic green-fluorescence of calcein. Cells incubated with $100 \mu \mathrm{g} / \mathrm{mL}$ of PJ preparation had lower cytoplasmic esterase activity, thus the decreased green-fluorescence of calcein was observed, as well as a lower number of attached cells. In that case, the PJ tested dose inhibited the cell proliferation to $25 \%$ and reduced the metabolic activity by $60 \%$.

\subsection{V. opulus Influence on Alkaline Phosphatase Activity}

The effect of $V$. opulus on the activity of alkaline phosphatase, which is essential for osteoblast mineralization, was tested with p-nitrophenyl phosphate (pNPP) assay.

As it is shown in Figure $4 \mathrm{~A}$, purified juice at $\mathrm{IC}_{0}$ dosage significantly increased ALP activity by $35 \%$, whereas fresh juice was able to elevate enzyme activity by almost $8 \%$. Cell incubation with ALP substrate (BCIP/NBT) and imaging with bright-field microscopy also confirmed the promotion of ALP activity by the samples. It can be seen in Figure 4B that cells treated with purified juice generated the largest amount of dark blue stained ALP product. Further studies showed that the observed elevation of enzyme activity was correlated with an $A L P$ gene expression increase at the transcription level, as shown in Figure 4C. Cells treated with the V. opulus purified juice exhibited a 1.5-fold increase in ALP mRNA expression, compared to the control cells. Fresh juice seemed to have no significant influence on the $A L P$ mRNA expression level. 


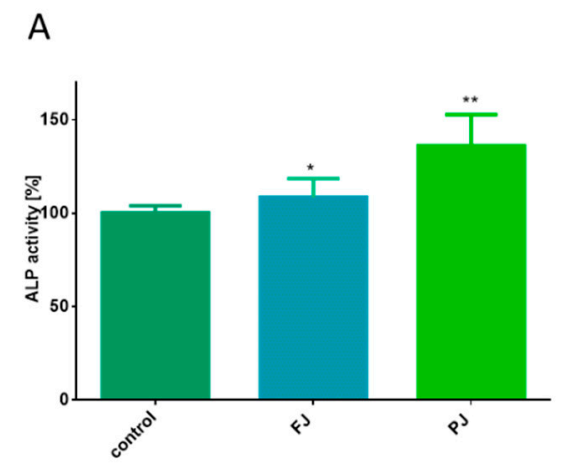

B
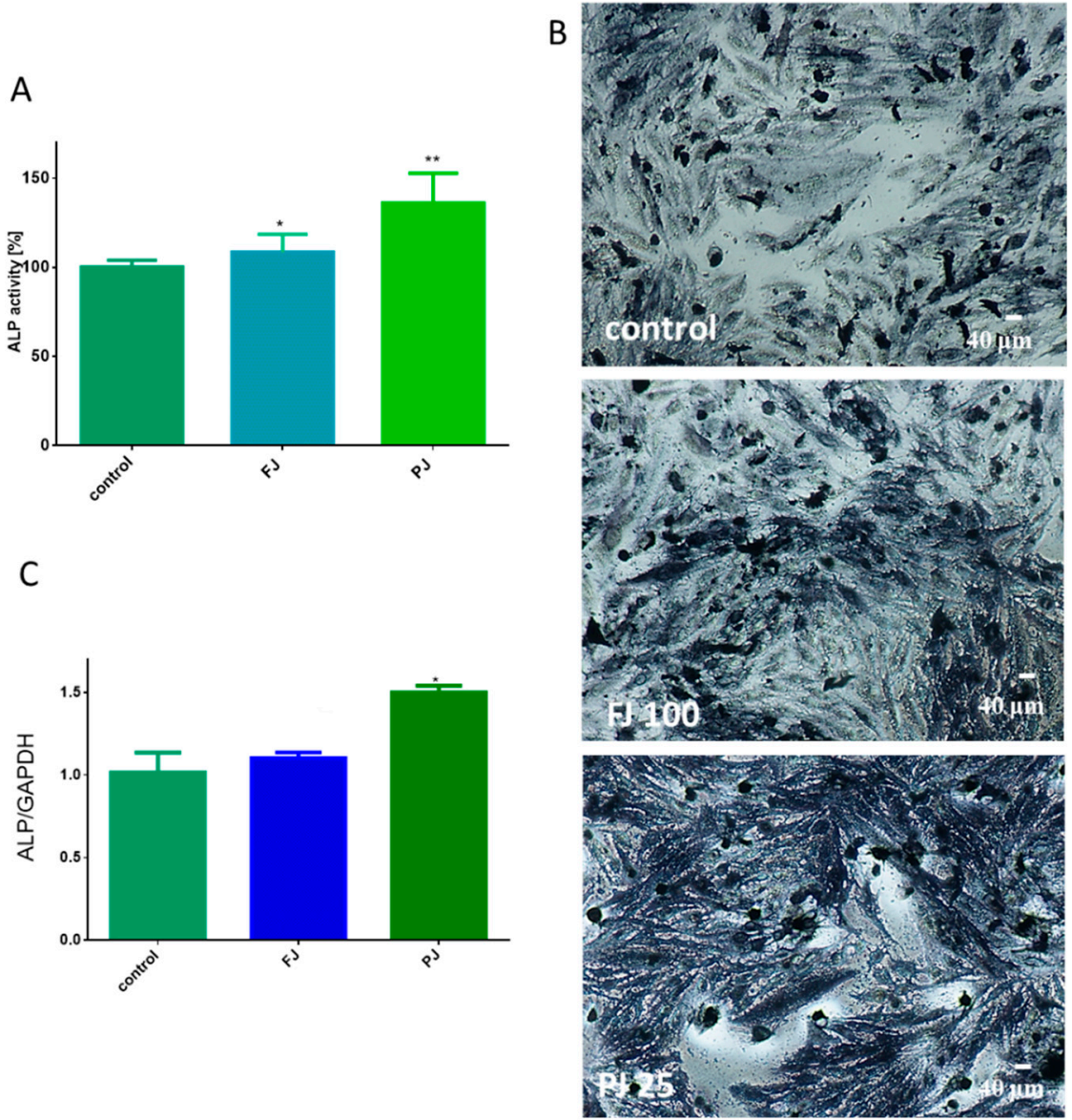

Figure 4. The influence of $V$. opulus FJ and PJ at $\mathrm{IC}_{0}$ dosage on Saos-2 cell alkaline phosphatase (ALP) activity, determined with pNPP assay after 8 days of exposure (A); control cells were not exposed to any compound; values are means $\pm \mathrm{SEM}, n \geq 12$. Cells observed in the presence of BCIP/NBT, known substrate for ALP, after their incubation with $100 \mu \mathrm{g} / \mathrm{mL}$ FJ and $25 \mu \mathrm{g} / \mathrm{mL} \mathrm{PJ} \mathrm{(B);} \mathrm{randomly} \mathrm{chosen} \mathrm{fields}$ were photographed at $\times 400$ with contrast-phase microscope. The expression of mRNA level of $A L P$ gene quantified by real-time PCR and normalized using glyceraldehyde-3-phosphate dehydrogenase $(G A P D H)$ as a reference gene $(n=4)(C)$. Statistical significance was calculated versus control cells (untreated), ${ }^{*} p \geq 0.05,{ }^{* *} p \geq 0.01$.

\subsection{V. opulus Influence on Matrix Mineralization}

The ability of Saos-2 cells to produce calcified extracellular matrix was confirmed with alizarin red S staining, which allows for the measurement of the amount of calcium deposited in the extracellular matrix.

Both $V$. opulus samples were able to stimulate the mineralization process after 8 days of treatment of Saos-2 cells. As presented in Figure 5A, fresh juice elevated the matrix mineralization by almost $15 \%$ in comparison to the control cells. That quantification data were followed by microscopic observations, which confirmed the appearance of red-stained round-shape granules related to the bone nodule formation, as shown in Figure 5B. After treatment with purified juice, Saos- 2 cells appeared to have a $60 \%$ increase in matrix calcification compared to the untreated cells. Purified juice preparation increased the size and number of mineralized granules, demonstrating its ability to stimulate osteogenic differentiation. 


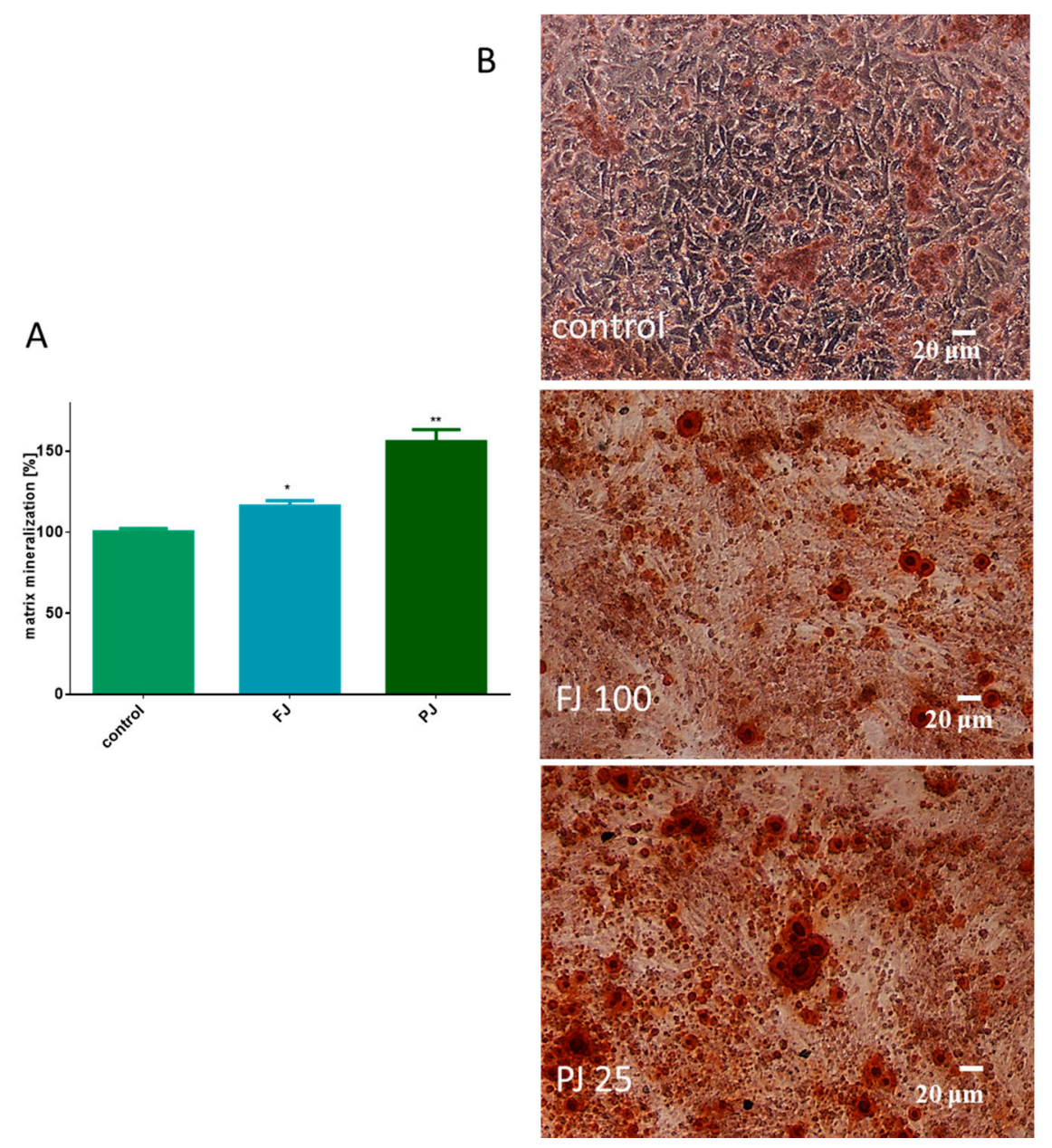

Figure 5. The influence of $V$. opulus $\mathrm{FJ}$ and $\mathrm{PJ}$ at $\mathrm{IC}_{0}$ dosage on Saos-2 cell matrix mineralization, determined by alizarin red $\mathrm{S}$ assay after 8 days of exposure (A); control cells were not exposed to any compound; values are means \pm SEM, $n \geq 12$; statistical significance was calculated versus control cells (untreated), ${ }^{*} p \geq 0.05,{ }^{* *} p \geq 0.01$. Cells stained with alizarin red $\mathrm{S}$ after their incubation with $100 \mu \mathrm{g} / \mathrm{mL}$ FJ and $25 \mu \mathrm{g} / \mathrm{mL}$ PJ (B); randomly chosen fields were photographed at $\times 200$ with contrast-phase microscope.

\subsection{V. opulus Influence on Expression of Genes Associated with Osteogenesis}

After cell treatment with $V$. opulus samples, the mRNA expression of selected osteogenic marker genes was determined by real-time PCR-Runt-related transcription factor 2 (RUNX2), type 1 collagen (COL1A1), osteonectin, receptor activator of nuclear factor kappa-B ligand $(R A N K L)$ and osteoprotegerin $(O P G)$. The data show that purified juice had a greater effect on gene expression at the transcription level than fresh juice, as shown in Figure 6.

The FJ sample increased the expression of RUNX2 mRNA levels by $40 \%$, whereas PJ by almost $60 \%$. Both samples upregulated the expression of COL1A1 mRNA by $80-95 \%$. The mRNA level of osteonectin was influenced only by PJ, which amplified the expression by $75 \%$. V. opulus samples had no effect on the expression of $O P G$, whereas a $15 \%$ decrease in the RANKL mRNA level was observed only for purified juice. 


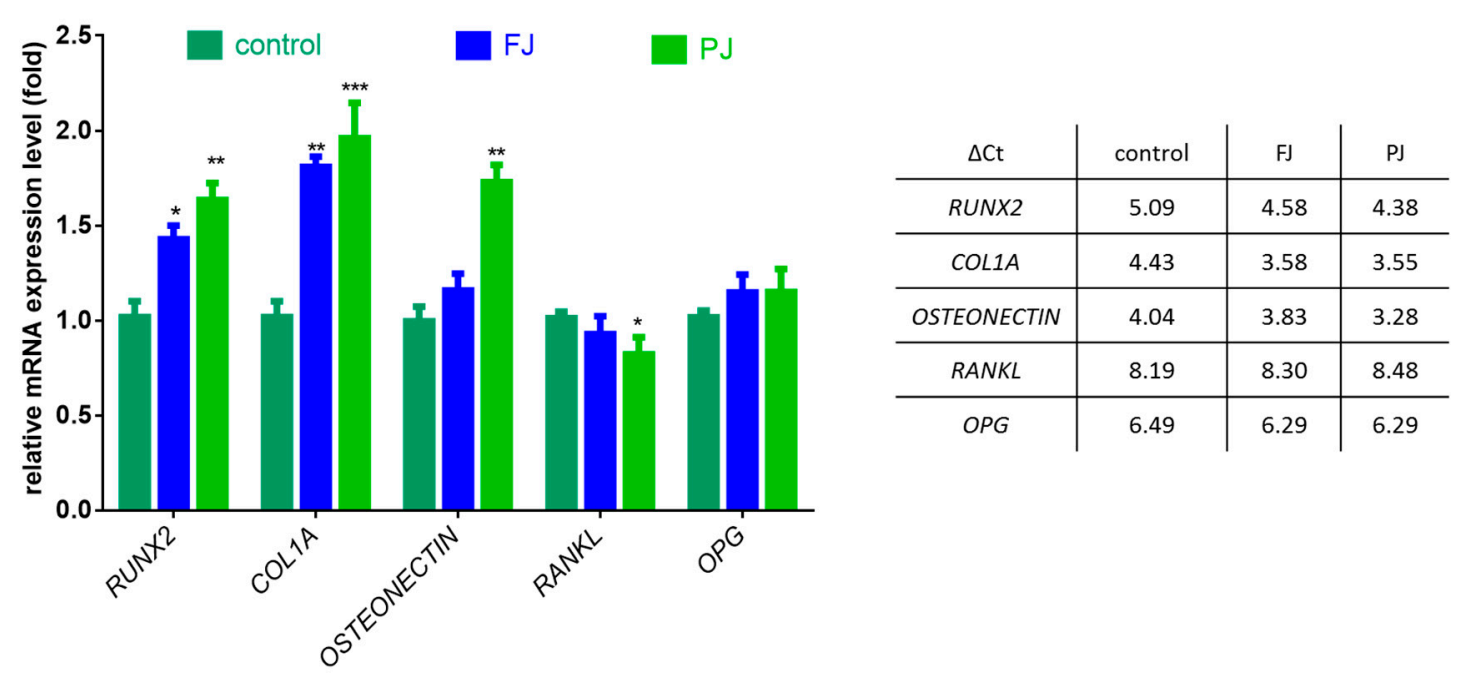

Figure 6. The influence of $V$. opulus $\mathrm{FJ}$ and $\mathrm{PJ}$ at $\mathrm{IC}_{0}$ dosage on the expression of selected genes in Saos- 2 cells after 8 days of exposure, quantified with real-time PCR and normalized using glyceraldehyde-3-phosphate dehydrogenase $(G A P D H)$ as a reference gene; $\triangle \mathrm{Ct}$ values are presented in table. Control cells were not exposed to any compound; values are means \pm SEM, $n=4$; statistical significance was calculated versus control cells (untreated), ${ }^{*} p \leq 0.05,{ }^{* *} p \geq 0.01,{ }^{* * *} p \geq 0.001$

\subsection{V. opulus Influence on Intracellular Reactive Oxygen Species Production and DNA Repair}

The influence of $V$. opulus juice on the regulation of intracellular reactive oxygen species (ROS) production by Saos- 2 cells was determined with dichloro-dihydro-fluorescein diacetate (DCFH-DA) assay. The results in Figure 7 show that cells treated with both samples of $V$. opulus at $\mathrm{IC}_{0}$ dosage declined intracellular ROS level by $10-20 \%$ in comparison to the control cells. The purified juice was more efficient as an oxidative stress reducer than fresh juice. Additionally, data show that the level of ROS changed depending on the PJ concentration studied. Cell treatment with $50 \mu \mathrm{g} / \mathrm{mL} \mathrm{PJ}$, a dose with previously demonstrated low cytotoxicity and decreasing metabolic activity of cells, as shown in Figures 2 and 3, elevated intracellular ROS generation, due to the induced mitochondria dysfunction. The further elevation of PJ dosage $(100 \mu \mathrm{g} / \mathrm{mL})$ significantly decreased the number of living cells, as well as attached cells, and thus the ROS level. Therefore, the observed significant reduction in intracellular ROS is not related to antioxidant ability but confirmed PJ cytotoxic potential. In our previous studies on $V$. opulus fruit preparation activity, we observed comparable patterns of their influence-low doses of preparations were cytoprotective against cells, whereas increased triggered mitochondrial membrane depolarization decreased the ATP level and activated caspase 9 and, finally, apoptosis [30].

To evaluate $V$. opulus cytoprotective potential against cellular DNA damage, firstly Saos-2 cells were challenged with methylnitronitrosoguanidine (MNNG) mutagen, then post-incubated with FJ and $\mathrm{PJ}$ samples at $\mathrm{IC}_{0}$ dose. DNA repair was measured at time zero, after 60 and $120 \mathrm{~min}$ of incubation. For the MNNG positive control, approximately $25 \%$ efficiency of DNA repair was observed after $120 \mathrm{~min}$ in comparison to the initial point. As presented in Figure 8A, both samples induced DNA repair in a statistically significant manner. V. opulus induced DNA repairs very efficiently after $60 \mathrm{~min}$ of incubation, and it was from 40 to $55 \%$ for PJ and FJ, respectively. The effect was significantly enhanced over $120 \mathrm{~min}$, where, for cells incubated with purified juice, DNA damage was approximately $50 \%$ lower than for the positive control. At that time point, the PJ sample was the strongest DNA repair inducer. Example images of typical comets are presented in Figure 8B. 


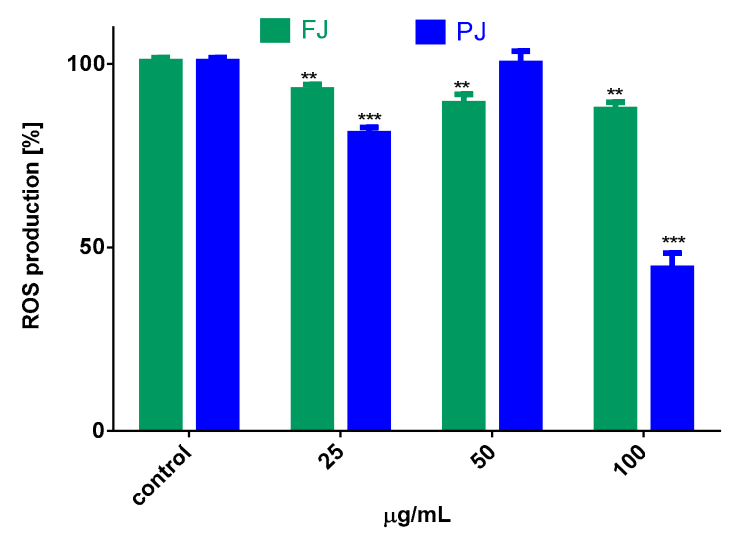

Figure 7. The influence of $V$. opulus $\mathrm{FJ}$ and $\mathrm{PJ}$ at $\mathrm{IC}_{0}$ dosage on intracellular ROS generation in Saos-2 cells after 8 days of exposure, quantified with DCFH-DA assay; control cells were not exposed to any compound; values are means $\pm \mathrm{SEM}, n \geq 9$; statistical significance was calculated versus control cells (untreated), ${ }^{* *} p \leq 0.01,{ }^{* * *} p \leq 0.001$.

A

B
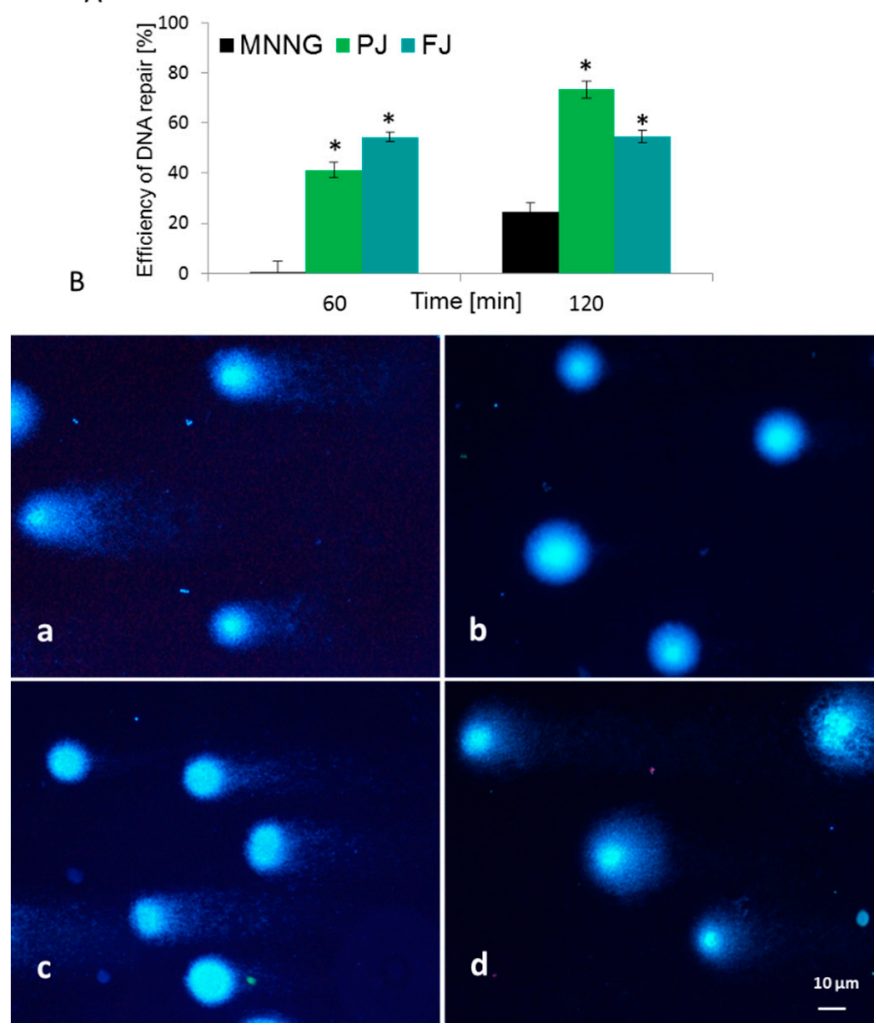

Figure 8. Efficiency of DNA repair (\%) in Saos-2 cells exposed to MNNG mutagen and post-incubated with V. opulus $\mathrm{FJ}$ and $\mathrm{PJ}$ at $\mathrm{IC}_{0}$ concentration (A). Typical images of comets stained with DAPI (B): (a) $6.8 \mu \mathrm{M}$ MNNG; (b) negative control on untreated cells; (c) PJ influence after $60 \mathrm{~min}$ and (d) $120 \mathrm{~min}$ of post-treatment. Fluorescence microscopy (Nikon, Tokyo, Japan); $\times 200$ magnification. ${ }^{*} p \leq 0.01$.

\subsection{V. opulus Influence on Pro-Inflammatory Markers: Il6, TNF $\alpha$ and VEGF Secretion}

Among cytokines, the most related to bone health are tumor necrosis factor $\alpha(\mathrm{TNF} \alpha)$ and interleukin 6 (Il6). In the case of TNF $\alpha$, only purified juice significantly declined the mRNA expression level by 25, compared to the control cells, as shown in Figure 9A. Taking into account the influence of $V$. opulus on protein secretion by cells, the $40 \%$ reduction in TNF $\alpha$ release was induced by PJ, whereas FJ downregulated this cytokine level to $90 \%$, as shown in Figure 9B. Simultaneously, both V. opulus 
probes diminished Il6 gene expression (by 15-30\%), as shown in Figure 9A, which was accompanied by a reduction in $\mathrm{Il6}$ protein secretion by Saos- 2 cells to $55-80 \%$, as shown in Figure $9 \mathrm{~B}$. As before, purified juice was a more effective inhibitor of interleukin 6 secretion by cells than FJ.

A

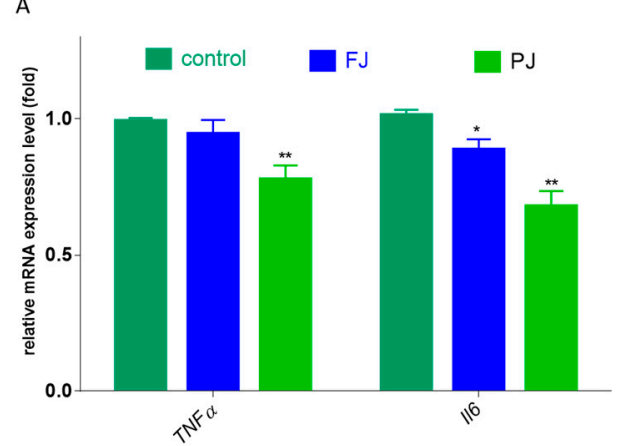

B

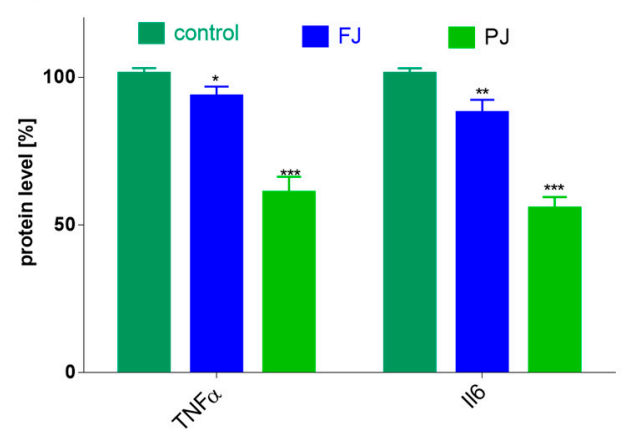

Figure 9. The influence $V$. opulus $\mathrm{FJ}$ and $\mathrm{PJ} \mathrm{at}_{\mathrm{IC}}$ on mRNA expression, quantified with real-time PCR and normalized using glyceraldehyde-3-phosphate dehydrogenase (GAPDH) as a reference gene (A) and protein secretion quantified with ELISA (B) of TNF $\alpha$ and Il6 in Saos- 2 cells after 8 days of exposure; control cells were not exposed to any compound; values are means $\pm \mathrm{SEM}, n=4$; statistical significance was calculated versus control cells $* x \leq 0.05,{ }^{* *} p \leq 0.01,{ }^{* * *} p \leq 0.001$.

Because bone formation via osteogenesis is sustained by angiogenesis, thus the influence of V. opulus on human umbilical vein endothelial cells (HUVEC) was studied. Both V. opulus samples at $\mathrm{IC}_{0}$ concentration, determined previously for Saos-2 cells, had no effect on HUVEC metabolic activity, as shown in Figure 10A, as well as cell morphology, as shown in Figure 10C. V. opulus phytocompounds had no influence on the secretion of the vascular endothelial growth factor (VEGF) involved in angiogenesis, as shown in Figure 10B.

A

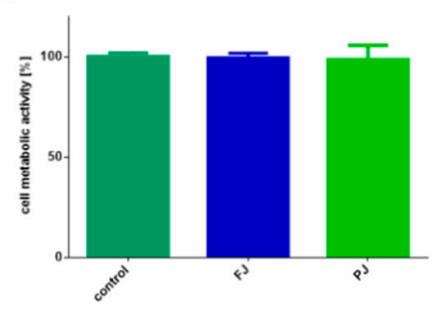

B

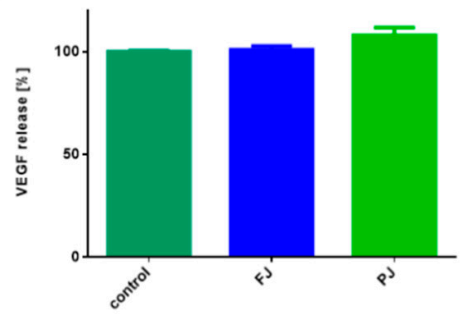

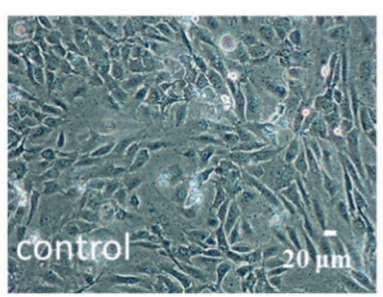
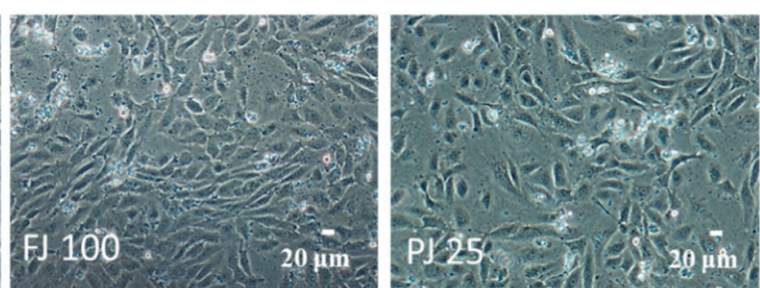

Figure 10. The influence V. opulus $\mathrm{FJ}$ and $\mathrm{PJ}$ at $\mathrm{IC}_{0}$ concentration on cellular metabolic activity, determined with Presto Blue assay (A) and VEGF secretion quantified with ELISA (B) by HUVEC cells; control cells were not exposed to any compound; values are means $\pm \mathrm{SEM}, n \geq 3$. Morphology of HUVEC cells treated with $V$. opulus for $48 \mathrm{~h}$ (C); randomly chosen fields were photographed at $\times 200$ magnification.

\subsection{Antimicrobial Activity of V. opulus Against Lactic Acid Bacteria and Pathogens}

Selected in our study beneficial bacteria (lactic acid bacteria) are a part of human gut microbiota, while the pathogens can contribute to dysbiosis, inflammation and acute diarrhea. Harmful bacteria 
can be responsible for the imbalance in the microbiota and can lead to the production of diverse metabolites causing dysbiosis and inflammation. The inflammation state (especially chronic) can be one of the main causes for this in the organism, which causes loss in bone biomass. Thus, in next step, we wanted to check the inhibitory activity of $V$. opulus juice in relation to beneficial and pathogenic bacteria. The antimicrobial activity of $V$. opulus is presented in Table 2 . The obtained results indicate that, within pathogenic bacteria, Gram-positive were more sensitive to V. opulus, than Gram-negative bacteria. S. aureus ATTC 6538 was the most sensitive to both samples with average inhibition zones of 12.5 and $9.0 \mathrm{~mm}$ for FJ and PJ, respectively. Ent. faecalis ATCC 29212 was the most sensitive to PJ, with the mean inhibition zone $10.0 \mathrm{~mm}$. L. monocytogenes ATCC 19115 was sensitive only to purified juice. The remaining pathogenic strains (i.e., Gram-negative as well as C. albicans ATCC 10231 yeast), were completely resistant to both tested samples. Generally, within pathogenic bacteria, V. opulus effectively only inhibited the growth of Gram-positive microorganisms.

Gram-positive lactic acid bacteria (LAB), which are the inhabitants of the human gastrointestinal tract and are considered to be beneficial for health, were totally resistant to tested $V$. opulus samples.

Table 2. The antimicrobial activity of V. opulus FJ and PJ.

\begin{tabular}{ccc}
\hline Strain & \multicolumn{2}{c}{ Inhibition Zone [mm] } \\
\cline { 2 - 3 } & FJ & PJ \\
\hline S. aureus ATTC 25923 & 2.0 & 7.0 \\
\hline S. aureus ATTC 6538 & 12.3 & 9.0 \\
\hline L. monocytogenes ATCC 19115 & 0 & 8.7 \\
\hline Ent. faecalis ATCC 29212 & 6.0 & 10.0 \\
\hline E. coli ATCC 10536 & 0 & 0 \\
\hline E. coli ATCC 8739 & 0 & 0 \\
\hline P. aeruginosa ATCC 15442 & 0 & 0 \\
\hline P. aeruginosa ATCC 24755 & 0 & 0 \\
\hline E. cloacae ATCC 13047 & 0 & 0 \\
\hline S. typhimurium ATCC 14028 & 0 & 0 \\
\hline S. enteritidis ATCC 13076 & 0 & 0 \\
\hline C. albicans ATCC 10231 & 0 & 0 \\
\hline Lb. rhamnosus GG & 0 & 0 \\
\hline Lb. plantarum ŁOCK 0981 & 0 & 0 \\
\hline Lb. brevis ŁOCK 0983 & 0 & 0 \\
\hline Lb. paracasei ŁOCK 0985 & 0 & 0 \\
\hline Lb. delbrueckii ŁOCK 0987 & 0 & 0 \\
\hline Lb. plantarum ŁOCK 0989 & 0 & 0 \\
\hline
\end{tabular}

\section{Discussion}

There is growing evidence of some phenolic compounds' beneficial impact in the prevention of oxidative stress-induced bone loss and osteoporosis [1,2,31]. Among fruits rich in these secondary metabolites and present in the human diet is V. opulus [24,32], thus the primary aim of the study was to evaluate its effect on the activity of human osteoblastic type Saos-2 cell lines. The V. opulus influence on Saos-2 mineralization was tested with two samples: fresh juice and purified juice (via solid-phase extraction). Nearly 30 phenolic compounds in Viburnum opulus fruit were identified, with the presence of chlorogenic acid, procyanidins, catechins and cyanidin glycosides being the most prominent [24,25]. As presented, the phenolic rich sample (PJ) obtained from FJ revealed stronger influence on the 
metabolic activity and proliferation of Saos-2 cells. Whereas none of the samples induced cellular proliferation, they caused a concentration-dependent influence on cellular activity, according to the content of phenolic compounds. Probably the most responsible for the observed activity of V. opulus is chlorogenic acid—quantitatively the main component of FJ and PJ—as well as procyanidins and catechins. Despite the fact that the concentration of phenolic compounds in PJ was almost 90-fold higher than in fresh juice, PJ dosage, able to decrease cellular activity by $50 \%$, was only 2.5 -times lower than FJ. Similarly, the obtained $\mathrm{IC}_{0}$ value for fresh juice was only 4-times higher than for PJ. Thus, it appears that the observed biological impact of $V$. opulus fresh juice is related to the presence of other non-phenolic compounds, such as sugars, proteins, organic acids, minerals, or other phenolics lost during solid-phase extraction and not detected in PJ. Specifically, potential synergic activities and chemical interactions may be responsible for the observed cellular effect. Still, the presented results are in agreement with our previous studies, where a phenolic rich fraction obtained from $V$. opulus was more active in Caco-2 and MIN-6 cells [24,30].

Saos- 2 cells can be differentiated to osteoblast-type cells in the presence of ascorbic acid and $\beta$-glycerol-phosphate [33]. Because the membrane-bound alkaline phosphatase enzyme is known as an early marker of osteoblast differentiation, essential for matrix mineralization, in the next step $V$. opulus influence on its activity was checked. As it was verified by ALP staining and quantitative activity analysis, both samples increased enzyme activity, leading to the elevation of the cellular phosphate concentration required for the initiation of hydroxyapatite formation. Indeed, alizarin red $S$ staining confirmed the enhanced generation of the calcified extracellular matrix, resulting from the accumulation of mineralizing ions, such as $\mathrm{Ca}^{2+}, \mathrm{HCO}_{3}{ }^{-}, \mathrm{CO}_{3}{ }^{2-}$ or $\mathrm{PO}_{4}{ }^{3-}$ [34]. Meanwhile, V. opulus induced the expression of mRNA level of osteogenic genes, such as RUNX2, COL1A1 and osteonectin, which indicated the promotion of Saos-2 cell osteoblast differentiation. Between the abovementioned proteins, the Runt-related transcription factor 2 is known as a key osteoblast differentiation regulator [18]. It binds to osteoblast specific cis-acting element (OSE) in the promoter region of the major osteoblast bone matrix protein genes and controls their expression [5]. The performed examination confirmed the enhancement of the RUNX2 level in Saos-2 cells incubated with FJ and PJ preparations. The treatment of Saos-2 cells with $V$. opulus samples was able to elevate $A L P$ gene expression. Simultaneously, further analysis established that collagen I gene expression on the transcription level was also upregulated. It is known that the production of type 1 collagen, which compromises $90 \%$ of the bone matrix, is the most important function of osteoblasts. Moreover, among other proteins regulated by RUNX2 transcription factor are osteonectin, promoting collagen mineralization, osteopontin inhibiting hydroxyapatite crystal growth and osteocalcin stimulating bone mineral maturation [18]. Purified juice was able to elevate the expression of the osteonectin mRNA level. Overall, $V$. opulus juice phytocompounds could be considered as agents of accelerating the mineralization process, enhancing osteoblast maturation through RUNX2 increase and, finally, of the suspected elevation of RUNX2 protein expression. We are aware that the main limitation of the presented study is the attempt to explain the $V$. opulus molecular mechanism associated with the stimulation of the Saos-2 osteogenesis process basing mainly on the selected genes transcription level analysis. Given that the presented results contribute to elucidating $V$. opulus as an inducer of bone matrix mineralization, further evaluation on protein levels should be performed. What is more, in the observed influence on the mineralization process, other mechanisms can be triggered, such as increased signaling of bone morphogenetic proteins (BMP), which results in the upregulation of RUNX2 factor. It was demonstrated that cryptochlorogenic and neochlorogenic acids present in dried plum extract upregulated MC3T3-E1 osteoblast activity by enhancing membrane-bound BMP2 signaling leading via phosphorylation to induce the expression of RUNX2 [35].

To the best of our knowledge, there are no reports of V. opulus fruit influence on osteogenesis regulation. Because the composition of FJ and $\mathrm{PJ}$ is very complex (more than 30 phenolic compounds were identified), it would be premature to infer that the osteogenic potential reported here results only from the main components present in preparations. However, there are data demonstrating the pro-osteogenic ability of some of the phenolic constituents, which were identified in V. opulus fruit. It is 
known that chlorogenic acid promoted osteogenesis in human adipose tissue-derived mesenchymal stem cells (hAMSCs), which was followed by the increase in mineralization with ALP and RUNX2 upregulation [36]. Studies performed with a melon extract containing chlorogenic acid demonstrated its protective activity against bone loss in rats with induced osteoporosis [37]. After the treatment of animals, calcium concentration and strength of bone were elevated, but ALP blood level was decreased. Rats with induced osteoporosis treated with chlorogenic acid $(9-45 \mathrm{mg} / \mathrm{kg} / \mathrm{d})$ had partially improved bone remodeling with ALP and osteocalcin elevation [38]. Studies performed in vitro with BMS cells demonstrated that chlorogenic acid induced cell differentiation by activating the cyclin D1 and phosphoinositide 3-kinase (PI3K)/Akt pathways [38]. Green tea catechin, (-)-epicatechin gallate (ECG), was shown to stimulate the osteoblast differentiation of $\mathrm{C} 3 \mathrm{H} 10 \mathrm{~T} 1 / 2$ and hMSC cells with the upregulation of RUNX2 transcription factor and the activation of p38 MAP kinase, which is critical for osteoblast differentiation [39]. In the observed mechanism, the activation of the transcription coactivator with PDZ-binding motif (TAZ) was involved. The TAZ protein interacts with the RUNX2 protein, but also acts with the peroxisome proliferator activated receptor $\gamma(\operatorname{PPAR} \gamma)$-it promotes osteogenesis through RUNX2-mediated gene transcription and suppresses adipogenesis through the PPAR $\gamma$ nuclear receptor [40,41]. Another catechin, (-)-epigallocatechin-3-gallate (EGCG), increased the osteogenic differentiation of bone marrow hMSC cells leading to matrix mineralization through the upregulation of RUNX2, ALP, osteonectin and osteocalcin mRNA levels [42]. Additionally, the expression of promoting osteoblast-maturation bone morphogenetic protein 2 (BMP2) at mRNA level was enhanced.

Bone formation by osteoblasts can be enhanced by the inhibition of bone resorption controlled by osteoclasts [43]. After the binding of the receptor activator of nuclear factor-kB ligand (RUNKL), present on the surface of an osteoblast, to the RANK receptor, found in osteoclasts, the activation of osteoclastogenesis occurs [44]. Osteoclast differentiation can be inhibited by osteoprotegerin, which captures and binds RANKL, preventing its binding with the receptor present in osteoclast. As it was demonstrated, the PJ sample decreased the RANKL mRNA level, while not showing any significant effect on OPG. The compound regulation of osteoclastogenesis is connected with its influence on the RANKL:OPG ratio [45]. According to these calculations of mRNA expression levels, the RANKL:OPG ratio after cell treatment with PJ was reduced by almost $30 \%$ in comparison to the control cells. Hence, it can be assumed that $V$. opulus components may stimulate bone formation via the stimulation of mineralization. Its anti-resorptive function-thus osteoclastogenesis inhibition preventing bone loss-needs to be verified with osteoclast cell line studies. Whereas we did not perform experiments in this regard, the chlorogenic acid potential in the reduction in osteoclast differentiation was demonstrated [46]. In the molecular mechanism of bone marrow macrophages (BMMs), osteoclast differentiation inhibition involved the suppression of RANKL-mediated NF- $\mathrm{KB}$ activation. Further studies performed in mice demonstrated that chlorogenic acid administrated orally at a dosage of $10 \mathrm{mg} / \mathrm{kg}$ was able to suppress lipopolysaccharide-mediated bone erosion [36]. The osteoclastogenesis process inhibition by EGCG was identified, with decrease of the RANKL/OPG ratio in murine stromal cells, ST2 cells and macrophage-like RAW 264.7 cells [45]. Grape pomace polyphenols were also shown to decrease RANKL/OPG ratio and elevate the expression of BMP2 and RUNX2 mRNA in human MSC cells [23].

Reactive oxygen species are known subcellular messengers, whose excessive production leads to ROS-induced DNA damage, protein and lipid peroxidation and cell death $[18,47,48]$. It was demonstrated that oxidative stress inhibits osteoblastic differentiation with NF-kB activation $[1,49]$. What is more, it activates osteoclastogenesis and strengthens bone resorption during osteoporosis, leading to bone structure collapse and the loss of bone mass [1,47]. Whereas the potential of V. opulus as the antioxidant and the scavenger of artificial free radicals was determined previously [24,25], here its positive influence on the intracellular oxidative stress of Saos-2 cells was verified. It may be suspected that $V$. opulus phenolics could directly react with intracellular free radical cations or could enhance the activity of the cellular detoxifying enzymes. As it was previously demonstrated, V. opulus treatment enhanced glutathione (GPx) peroxidase activity in insulinoma MIN6 cells [30]. Still, the observed 
decrease in intracellular ROS level was in accordance with detected ALP and RUNX2 elevation and matrix mineralization [49]. These $V$. opulus features are relevant in regard to the prevention of bone damage induced by oxidative stress accompanying the elevation of blood glucose or free fatty acids levels during the obesity state [16]. Additionally, V. opulus revealed cytoprotective properties against DNA damage induced by MNNG. Increase in DNA repair process efficiency by $V$. opulus was noted previously in Caco-2 cells [24]. Cytoprotective properties against hydroperoxide-induced apoptosis in osteoblastic cells MC3T3-E1 revealed grape seed proanthocyanidins [50], the group of compounds also present in $V$. opulus juice.

The elevation of proinflammatory cytokines Il6 and TNF $\alpha$ is considered an osteoresorptive factor [51]. These proteins stimulate osteoclastogenesis and enhance bone resorption with the elevation of RANKL expression in osteoblasts. The observed decrease in Il6 and TNF $\alpha$ proteins expression and secretion in Saos-2 cells treated with purified juice is reflected in the decrease in RANKL mRNA level. Polyphenolic extracts from black, green and rooibos tea, rich in catechins, induced mineralization and ALP activity in Saos2 cells, which was followed by TNF $\alpha$ and Il6 inflammatory cytokine reduction [52]. On the other hand, obesity is associated with low-grade chronic inflammation, where the enlargement of adipocytes induces the secretion of TNF $\alpha$ and Il6, leading not only to insulin resistance but also to bone loss $[9,53]$. The anti-inflammatory property of chlorogenic acid was connected with oxidative stress decrease, the attenuation of NF- $\mathrm{kB}$ activation and, finally, TNF $\alpha$ and Il6 production [54]. Thus, the downregulation of $\mathrm{Il} 6$ and TNF $\alpha$ secretion by V. opulus is relevant not only for bone metabolism but it also has an impact on obesity state, contributing to osteoporosis delay. In this regard, further studies are required to assess $V$. opulus influence on the adipogenesis process and cytokine production by adipocytes.

Bone regeneration is sustained by the formation of blood vessels serving as a source of nutrients, oxygen, signaling molecules and ions used for mineralization, as well as for bone forming precursor cells [55]. Therefore, we investigated the influence of $V$. opulus on HUVEC cells able to migrate and involved in blood vessel formation. V. opulus samples at $\mathrm{IC}_{0}$ dose effectively inducing Saos-2 differentiation had no influence on HUVEC cell metabolic activity, as well as on VEGF secretion. That endothelial cell-specific mitogen promotes angiogenesis and accelerates bone healing through the promotion of progenitor cell differentiation into osteoblasts [55]. Studies performed on HUVEC cells under hypoxic conditions identified chlorogenic acid as an inhibitor of the angiogenesis process, able to decrease VEGF secretion [56]. However, chlorogenic acid was not able to inhibit VEGF-dependent VEGFR-2 activation in HUVEC cells, triggering angiogenesis [57]. Taking into account the obtained results, it can be hypothesized that other juice components may stimulate VEGF secretion, influencing a final cellular response in this regard. Another factor relevant for angiogenesis is cellular migration. Studies performed with a blueberry extract rich in chlorogenic acid demonstrated the enhancement of HUVEC cell migration [58]. On the other hand, in a mouse model with osteoarthritis, the animals' treatment with grapes procyanidins was shown to downregulate VEGF, TNF $\alpha$, Il6 and RANKL expression, protecting the cartilage integrity [59]. Thus, the observed in vitro efficacy of $V$. opulus phenolic compounds in bone mineralization needs further in vivo studies performed with animal models treated with a high-fat diet and with induced osteoporosis.

For studies on the osteogenesis process of Saos- 2 cells, $V$. opulus samples at $\mathrm{IC}_{0}$ concentration (25 and $100 \mu \mathrm{g} / \mathrm{mL}$ ) were chosen, thus without a cytotoxic impact on cell viability and division. Studies performed with another phenolic compound, biochanin A, showed that its consumption of $5 \mathrm{mg}$ per day (which corresponds to $1 \mu \mathrm{M}$ ) prevented bone loss effectively at a safe range level of its intake [51]. Taking into account that the mean polyphenol intake of an adult subject is about 283-1000 mg total polyphenols/day, the V. opulus phenolic compound concentrations used in this work can be achieved in the gut under physiological conditions [14]. Given the human studies, the maximum plasma concentration $\left(\mathrm{C}_{\max }\right)$ of chlorogenic acids and metabolites varies depending on the dose, individual and analytical methodology used in the study, from $\mathrm{nM}$ to low $\mu \mathrm{M}$ levels [60]. Given the molar mass of chlorogenic acid $(354.31 \mathrm{~g} / \mathrm{mol})$, the concentration ranges from $1 \mathrm{nM}$ to $1 \mu \mathrm{M}$ correspond 
to a concentration from 0.35 to $354 \mu \mathrm{g} / \mathrm{L}$. According to Farah et al. [61] chlorogenic acids present in green coffee are strongly absorbed and metabolized in humans. Maximum plasma concentration $\left(C_{\max }\right)$ varied significantly between subjects and phenolic acid structure. For example, the $C_{\max }$ of all chlorogenic acids ranged from 0.6 to $16.9 \mu \mathrm{M}$ and, for dicaffeoylquinic acids, ranged from 0.3 to $22.8 \mu \mathrm{M}$. In this human study, the chlorogenic acid $\mathrm{C}_{\max }$ (dominant phenolic compounds in our extracts) was $5.9 \mu \mathrm{M}$ or $2.1 \mathrm{mg} / \mathrm{L}$ for a consumed dose of $42 \mathrm{mg}$ chlorogenic acid. Thus, our effective dose of purified juice $(25 \mathrm{mg} / \mathrm{L})$ contained $16 \mathrm{mg} / \mathrm{L}$ chlorogenic acid. Additionally, $V$. opulus phenolics' binding affinity to human serum albumin may effectively regulate their bioavailability and cellular metabolism [22,30]. Data indicate that phenolic compounds, as well as chlorogenic acids, are metabolized by gut microbiota, and then their aglycons and other metabolites are absorbed in the small intestine by passive diffusion or with transporters [62]. Subsequently, V. opulus compounds bound to blood albumin could be delivered to bone forming cells and regulate their metabolism. Despite observed compound biotransformation in the intestine, meanwhile, they influence the growth and viability of gut microbiota [63]. Therefore, next, the impact of $V$. opulus on selected microorganism growth was investigated. Among the studied pathogens the antimicrobial activity of both samples was detected against Gram-positive bacteria. It could be suspected that the observed antibacterial action involves phenolic compounds targeting the rigidity, permeability or integrity of bacterial cell wall and membrane, as well as interaction with enzymes involved in bacterial metabolism [64]. Chlorogenic acid and procyanidins from grape seeds were shown to act against $S$. aureus and L. monocytogenes $[65,66]$. Simultaneously, the growth of Gram-positive lactic acid bacteria was not inhibited. The intestinal presence of these bacteria and their metabolic byproducts defend the organism against freshly ingested pathogen microorganisms, as well as protects against intestinal injury and inflammation [67]. In this regard, the feature of $V$. opulus to inhibit pathogenic bacteria without the inhibition of beneficial microorganisms is very relevant. The presented results are in line with other studies performed on mice with a high-fat diet [68]. Animals treatment with chlorogenic acid $(150 \mathrm{mg} / \mathrm{kg} / \mathrm{d})$ promoted an increase in the relative abundance of Lactobacillaceae and Bacteroidaceae, as well as body loss and the reduction in plasma lipid levels. What is more, microbial dysbiosis (infection) can lead to inflammation processes and contribute to bone loss. Additionally, alterations in composition and the diversity of microbiota is correlated with many inflammatory and metabolic disorders (e.g., inflammatory bowel disease, obesity), which can change the permeability of intestinal cells. The gut microbiota can interact with the host immune system and further influence the host health. It was proven that gut microbiota plays a crucial role in bone metabolism and mass through immune and endocrine systems and calcium balance (cellular transport and absorption), but the exact mechanism is still unclear [69]. Some beneficial bacteria, such as Lactobacillus salivarius UCC 118, stimulate calcium uptake by enterocytes in in vitro models [70], whereas L. rhamnosus GG was shown to stimulate bone improvement in estrogen-deficient mice [71]. What is more, some products of lactic acid bacteria fermentation were also able to increase intestinal calcium absorption [72]. There are many reports linked to the beneficial effect of probiotic bacteria on estrogen deficiency-induced bone loss, which was well summarized in the review article by $\mathrm{Xu}$ et al. [72]. Reduced bone mass density is rather associated with taxon-specific signatures in the gut microbiota [73]. The composition of the cell wall of many Gram-negative bacteria (lipopolysaccharide and endotoxin) play an important role in bone metabolism [74]. In our study, V. opulus samples did not inhibit the growth of beneficial Lactobacillus species, which means that, when consumed together, they fulfil their protective functions, also linked to osteoporosis. What is more, these Lactobacillus strains could probably be useful in the fermentation of $V$. opulus juice with new pro-health properties, which will be the subject of our further research. 


\section{Materials and Methods}

\subsection{Chemicals and Reagents}

All cell culture reagents were obtained from Life Technologies (Carlsbad, CA, USA). Methylnitronitrosoguanidine (MNNG), Low Melting Point (LMP) agarose, Normal Melting Point (NMP) agarose, NaCl, Triton X-100, EDTA, Tris, NaOH and 4',6-diamidino-2-phenylindole (DAPI) were purchased from Sigma-Aldrich (St. Louis, MO, USA). Other chemicals used, if not stated otherwise, were obtained from Sigma-Aldrich (Steinheim, Germany).

\subsection{Preparation of V. opulus Samples, Identification and Quantitative Determination of Individual Phenolic Compounds by UPLC-PDA-Q/TOF-MS}

Fresh fruits of the $V$. opulus were collected from Rogów Arboretum, Warsaw University of Life Sciences (Rogów, Poland) and authenticated with the account number 18162. Fresh juice (FJ) was obtained from homogenized fruit pulp, which was further centrifuged (5000 rpm for $10 \mathrm{~min}$ ). Solid phase extraction with C-18 Sep-Pak cartridge and methanolic elution (10 g capacity, Waters Corp., Milford, MA, USA; 12-Port Vacuum Manifold system) was performed to isolate phenolic compounds from juice, to lyophilize and to obtain purified juice (PJ). The identification of individual phenolic compounds was performed according to the protocol described in our previous work [29] using a Waters UPLC ${ }^{\mathrm{TM}}$ system (Waters Corporation, Miliford, MA, USA) with an Acquity UPLC HSS T3 C18 column $(150 \times 2.1 \mathrm{~mm}, 1.8 \mu \mathrm{m}$; Waters Corp., Milford, MA, USA) and a quadruple-time-of-flight mass spectrometer (Q/TOF-MS) (Waters Corp., Milford, MA, USA), equipped with electrospray ionization (ESI). The mobile phase consisted of (A) $0.1 \%$ formic acid in water and (B) acetonitrile (B). The UPLC elution conditions were as follows: initial conditions $99 \%(\mathrm{~A}) ; 12 \mathrm{~min} 65 \%$ (A); $12.5 \mathrm{~min} 100 \%$ (B); $13.5 \mathrm{~min} 99 \%$ (A). The flow rate was $0.45 \mathrm{~mL} / \mathrm{min}$. The mass spectrometer was operating in the negative mode for a mass range of 150-1500 Da, fixed source temperature at $100{ }^{\circ} \mathrm{C}$, desolvation temperature at $250{ }^{\circ} \mathrm{C}$, desolvation gas flow of $600 \mathrm{~L} / \mathrm{h}$, cone voltage of $45 \mathrm{~V}$, capillary voltage of $2.0 \mathrm{kV}$ and a collision energy of $50 \mathrm{~V}$. Leucine enkephalin was used as a lock mass. The instrument was controlled by Mass-LynxTM V 4.1 software (Waters Corp., Milford, MA, USA). Phenolic compounds were monitored for flavanols at $280 \mathrm{~nm}$, hydroxycinnamic acids at $320 \mathrm{~nm}$, flavonols at $360 \mathrm{~nm}$, and anthocyanins at $520 \mathrm{~nm}$. Photodiode detector spectra were measured over the wavelength range 200-600 nm. Phenolic compounds were identified using their retention time, UV-Vis characteristic and MS and $\mathrm{MS}^{2}$ properties, using data gathered in-house and from literature, as described in the previous work [29]. The identified compounds were quantified against a standard curve of peak areas of standard substances $((+)$-catechin, $(-)$-epicatechin, procyanidin B1, B2 and C1, chlorogenic acid, cryptochlorogenic acid, neochlorogenic acid, cyanidin-3-glucoside, cyanidin-3-sambubioside, cyanidin-3-rutinoside, quercetin 3-rutinoside and quercetin 3-glucoside). The results were calculated as $\mathrm{mg}$ of compound in $1 \mathrm{~g}$ of freeze-dried fresh juice or purified juice. For biological studies, tested samples were dissolved in a PBS/DMSO $(1: 1 v / v)$ at concentrations presented in the descriptions of the tests carried out.

\subsection{Cell Culture}

Studies were performed with Saos-2 cell line-human osteosarcoma cells obtained from American Type Culture Collection (Manassas, VA, USA). Saos-2 cells were grown in low glucose Dulbecco's Modified Eagle's Medium (DMEM) with 10\% fetal bovine serum (FBS) supplemented with 100 U/mL penicillin, $100 \mu \mathrm{g} / \mathrm{mL}$ streptomycin and $25 \mu \mathrm{g} / \mathrm{mL}$ amphotericin B. For osteogenesis stimulation medium, consisting of DMEM-low glucose completed with 2-Phospho-L-ascorbic acid (100 $\mu \mathrm{M})$, L-proline $(34.8 \mu \mathrm{M})$ and $\beta 2$-glycerol phosphate $(5 \mathrm{mM})$ was added [33]. For all experiments, if not stated otherwise, Saos- 2 cells were seeded into a 96-well plate at a density of $10^{4}$ cells/well in complete medium and grown overnight. After 24 h, medium was changed with fresh osteogenic medium containing tested compounds for 8 days. The medium was changed every two days and fresh potion of 
compounds was added. Cells were maintained at $37^{\circ} \mathrm{C}$ in a humidified incubator containing $5 \% \mathrm{CO}_{2}$. All the experimental measurements were performed using the Synergy 2 BioTek Microplate Reader (BioTek, Winooski, VT, USA). Microscopic observations were performed using a contrast-phase and fluorescent microscope, Nikon TS100 Eclipse (Nikon, Tokyo, Japan) under $\times 200$ magnification, if not stated otherwise.

\subsection{Cell Viability and Proliferation}

Saos-2 cells were seeded into a 96-well plate at a density of $10^{4}$ cells/well in complete medium and grown overnight. Then, the medium was changed into osteogenic medium and cells were incubated in the presence of $V$. opulus samples diluted in culture medium for $48 \mathrm{~h}$. PrestoBlue (Life Technologies, Carlsbad, CA, USA) reagent was used for $30 \mathrm{~min}$ to quanitify the metabolic activity of cells according to the manufacturer's instructions (fluorescence measurement at F530/590 nm). Cell proliferation was evaluated with the CyQUANT Direct Cell Proliferation Assay (Life Technologies, Carlsbad, CA, USA), according to the manufacturer's instructions, by measuring the fluorescent signal at F485/528 nm.

\subsection{Detection of Intracellular Reactive Oxygen Species Generation}

The effect of samples on the intracellular generation of reactive oxygen species (ROS) was checked with dichloro-dihydro-fluorescein diacetate (DCFH-DA) dye. After cell treatment with V. opulus, the medium was changed into phosphate buffer saline (PBS), $10 \mu \mathrm{M}$ probe was added for $30 \mathrm{~min}$ and fluorescence at $\mathrm{F} 485 / 530 \mathrm{~nm}$ was measured.

\subsection{DNA Damage and Repair}

V. opulus samples were investigated in terms of their ability to induce DNA repair in Sao-2 cells that had been exposed to mutagen-methylnitronitrosoguanidine (MNNG). The research was conducted according to Nowak et al. (2015) with some modifications [75]. So, as to examine DNA repair, the cells were damaged with $6.8 \mu \mathrm{M}$ MNNG for $10 \mathrm{~min}$ on ice. Next, the cells were centrifuged $\left(182 \times \mathrm{g}, 4^{\circ} \mathrm{C}, 15 \mathrm{~min}\right.$ ), resuspended in fresh medium and exposed (for 60 and $120 \mathrm{~min}$ at $37^{\circ} \mathrm{C}$ ) to the final concentrations without cyto- and genotoxicity. At the start ( $0 \mathrm{~min})$, and, after 60- and 120-min incubations, aliquots of the suspensions were taken and, to stop the DNA repair in cells, the samples were placed in an ice bath. At each time interval, an alkaline comet assay $(\mathrm{pH}>13)$ was performed and DNA repair was quantified by the determination of the extent of residual DNA damage. The positive control were cells exposed to MNNG, while the negative control consisted of Saos-2 cells in medium. In the comet assay, the final concentration of cells in each sample was adjusted to $10^{5}$ cells $/ \mathrm{mL}$. The comet assay was performed as previously described [75]. After each incubation, aliquots of suspended cells were centrifuged $\left(182 \times g, 15 \mathrm{~min}, 4^{\circ} \mathrm{C}\right)$, decanted, suspended in $0.75 \%$ LMP agarose and distributed onto slides precoated with $0.5 \% \mathrm{NMP}$ agarose and immersed in lysing solution containing $2.5 \mathrm{M} \mathrm{NaCl}$, $1 \%$ Triton X-100, $100 \mathrm{mM}$ EDTA and $10 \mathrm{mM}$ Tris, $\mathrm{pH} 10\left(4^{\circ} \mathrm{C}, 1 \mathrm{~h}\right)$. After lysis, the slides were subjected to horizontal gel electrophoresis and DNA was allowed to unwind for $20 \mathrm{~min}$ in an electrophoretic solution containing $300 \mathrm{mM} \mathrm{NaOH}$ and $1 \mathrm{mM}$ EDTA. Electrophoresis was conducted at $4{ }^{\circ} \mathrm{C}$ for $30 \mathrm{~min}$ at an electric field strength of $0.73 \mathrm{~V} / \mathrm{cm}(300 \mathrm{~mA})$. Then, the slides were neutralized with distilled water for $5 \mathrm{~min}$, stained with $1 \mathrm{mg} / \mathrm{mL} 4^{\prime}, 6^{\prime}$-diamidino-2-phenylindole (DAPI) and covered with cover slips. The comets were visualized at $\times 200$ magnification with a fluorescence microscope (Nikon Eclipse Ci H600L, Nikon, Tokyo, Japan) attached to a digital camera (Nikon Digital Sight DS-U3, Nikon, Tokyo, Japan) and connected to a personal computer-based image analysis system, Lucia-Comet v. 7.0 (Laboratory Imaging, Prague, Czech Republic). Fifty images were randomly selected from each sample and the percentage of DNA in the comet tail was measured. The results were presented as mean \pm standard error of the mean (S.E.M.). 


\subsection{Alizarin Red Cells Staining}

After 8 days of incubation with $V$. opulus samples, the Saos-2 cells were washed with PBS and fixed with $5 \%$ formaldehyde solution for $30 \mathrm{~min}$ at room temperature [22,76]. After cell rinsing with water-staining, a solution of $1 \%$ alizarin red $\mathrm{S}$ in $2 \%$ ethanol ( $\mathrm{pH} 4.0)$ was added for $30 \mathrm{~min}$. Then cells were rinsed five times with destilled water and observed under a microscope. To quantify the matrix mineralization, cells were incubated with $100 \mathrm{mM}$ cetylpyridinium chloride for $1 \mathrm{~h}$ with gentle shaking. The absorbance of solubilized calcium-bound alizarin red $S$ was measured at $570 \mathrm{~nm}$.

\subsection{Estimation of Alkaline Phosphatase Activity}

After treatment with $V$. opulus samples, Saos-2 cells were washed with PBS, then $1.0 \mathrm{mg} / \mathrm{mL}$ p-nitrophenyl phosphate (pNPP) in $0.2 \mathrm{M}$ Tris buffer as the substrate for alkaline phosphatase (ALP) was added for $15 \mathrm{~min}$ and absorbance at $405 \mathrm{~nm}$ was measured [22]. To visualize ALP activity in cells, BCIP (5-bromo-4-chloro-3-indolyl phosphate)/ NBT (nitroblue tetrazolium) substrate was added.

\subsection{Gene Expresssion Analysis}

To study the influence of $V$. opulus on gene expression, Saos-2 cells were seeded into a 6-well plate at a density of $2 \times 10^{5}$ cells/well in complete medium and grown overnight. After $24 \mathrm{~h}$, medium was changed with fresh osteogenic medium containing tested compounds for 8 days. Total RNA was extracted from Saos- 2 cells after 8 days incubation with V. opulus samples using GeneMatrix Universal RNA Purification Kit (Eurex Ltd., Gdansk, Poland), according to the manufacturer's procedure. RNA samples were purified with Amplification Grade DNase I and reverse transcribed with NG dART RT Kit (Eurex Ltd., Gdansk, Poland). Real time RT-PCR was carried out using SG qPCR Master Mix (Eurex Ltd., Gdansk, Poland) on a BioRad CFX96 qPCR System (Bio-Rad, Hercules, CA, USA). Complementary DNA, representing $6 \mathrm{ng}$ total RNA per sample, was subjected to 25-40 cycles of PCR amplification. Samples were first incubated at $95{ }^{\circ} \mathrm{C}$ for $40 \mathrm{~s}$, then at $55^{\circ} \mathrm{C}$ for $30 \mathrm{~s}$, and finally at $72{ }^{\circ} \mathrm{C}$ for $30 \mathrm{~s}$. To exclude non-specific products and primer-dimers, after the cycling protocol, a melting curve analysis was performed by maintaining the temperature at $52{ }^{\circ} \mathrm{C}$ for $2 \mathrm{~s}$, followed by a gradual temperature increase to $95^{\circ} \mathrm{C}$. The threshold cycle $(\mathrm{Ct})$ values for that gene did not change in independently performed experiments. The level of target gene expression level was calculated as $2^{-\Delta \Delta C t}$, where

$$
\Delta \Delta C \mathrm{t}=[\mathrm{Ct}(\text { target })-C \mathrm{t}(G A P D H)]_{\text {sample }}-[C \mathrm{t}(\text { target })-C \mathrm{t}(G A P D H)]_{\text {control }}
$$

Gene expression was normalized using constitutively expressed glyceraldehyde-3-phosphate dehydrogenase $(G A P D H)$ as a reference gene. The following primer sequences were used to determine the genes' expression: RUNX2 5'-CAGTTCCCAAGCATTTCATCC-3' (F) and 5'-TCAATATGGTCGCCAAACAG-3' (R); ALP 5'-ACCTCGTTGACACCTGGAAG-3' (F) and 5'-CCACCATCTCGGAGAGTGAC-3' (R); COL1A1 5'-GCCAAGACGAAGACATCCCA-3' (F) and 5'-CACCATCATTTCCACGAGCA-3' (R); RANKL 5'-GAGTTGGCCGCAGACAAGA-3' (F) and 5'-TTGGAGATCTTGGCCCAACC-3' (R); OPG 5'-CAGCGGCACATTGGAC-3' (F) and 5'-CCCGGTAAGCTTTCCATCAA-3' (R); Il6 5'-TGGCTGAAAAAGATGGATGCT-3' (F) and 5'-AACTCCAAAAGACCAGTGATGATT-3' (R); TNF $\alpha$ 5'-CCCAGGCAGTCAGATCATCTTC-3' (F) and 5'-AGCTGCCCCTCAGCTTGA-3' (R); OSTEONECTIN 5'-GTGCAGAGGAAACCGAAGAG-3' (F) and 5'-CGATAGGCCTCCTGAAAGC-3' (R); GAPDH 5'-CCACCCATGGCAAATTCCATGGCA-3' (F) and 5'-TCTAGACGGCAGGTCAGGTCCACC-3' (R). Data analyses were obtained from at least three independent experiments.

\subsection{Determination of Selected Proteins Levels}

To study $V$. opulus influence on cytokine secretion, Saos-2 cells were seeded into a 24-well plate at a density of $4 \times 10^{4}$ cells/well in complete medium and grown overnight. After $24 \mathrm{~h}$, medium was 
changed with fresh osteogenic medium containing tested compounds for 8 days. On the last day of cell treatment, the medium was collected and protein concentrations of Il6 (Human IL6 ELISA kit, Biorbyt Ltd., Cambridge, GB) and TNF $\alpha$ (Human TNF alpha ELISA kit, Biorbyt Ltd., Cambridge, GB) were determined using ELISA kits, following the manufacturer's instructions. Briefly, the collected medium samples were incubated for $2 \mathrm{~h}$ at room temperature to allow the cytokine binding to the well by the immobilized antibody. After washing, the plates were incubated for $1 \mathrm{~h}$ with biotinylated anti-human TNF alpha or anti-human Il6 antibodies, respectively. After washing, HRP-conjugated streptavidin or avidin-biotin-peroxidase complex was added, respectively, for $45 \mathrm{~min}$. After washing, a $3^{\prime}, 5,5^{\prime}$-tetramethylbenzidine (TMB) substrate solution was added for blue color development. After the addition of the stop solution, the absorbance was measured at $450 \mathrm{~nm}$. In cell lysates obtained with $0.1 \%$ Triton X-100 with PBS, the protein level was quantified with the Bradford assay. The cytokine levels were normalized to protein content.

\subsection{Antimicrobial Activity of V. opulus Juice}

In the research, twelve strains of pathogens were used. Within the pathogens there were seven Gram-negative: Escherichia coli ATCC 10536; E. coli ATCC 8739; Pseudomonas aeruginosa ATCC 15442; P. aeruginosa ATCC 24755; Enterobacter cloacae ATCC 13047; Salmonella Typhimurium ATCC 14028; Salmonella Enteritidis ATCC 13076. There were four Gram-positive species: Staphylococcus aureus ATTC 25923; S. aureus ATTC 6538; Enterococcus faecalis ATCC 29212; Listeria monocytogenes ATCC 19115. Additionally, one yeast strain-Candida albicans ATCC 10231-was engaged. The abovementioned strains were obtained from American Type Culture Collection (ATCC; Manassas, VA, USA). Moreover, six strains of lactic acid bacteria (LAB, Gram-positive) were applied: Lactobacillus rhamnosus GG (commercial strain); Lactobacillus plantarum ŁOCK 0981; Lactobacillus brevis ŁOCK 0983; Lactobacillus paracasei ŁOCK 0985; Lactobacillus delbrueckii ŁOCK 0987; Lb. plantarum ŁOCK 0989. Lb. rhamnosus GG was isolated from Dicoflor. The remaining strains were acquired from the collection of the Institute of Fermentation Technology and Microbiology (ŁOCK 105), Lodz University of Technology, Poland. Selected strains were stored with the usage of Cryobanks ${ }^{\mathrm{TM}}$ (Copan Diagnostics Inc., Murrieta, CA, USA) at $-22{ }^{\circ} \mathrm{C}$. Before analysis, both LAB as well as pathogens were activated and passaged twice in de Man, Rogosa and Sharpe broth (MRS; Merck-Millipore, Darmstadt, Germany), nutrient broth with glucose (Merck-Millipore, Darmstadt, Germany) or YPG (yeast extract-peptone glucose medium; yeast extract $10 \mathrm{~g} / \mathrm{L}$; peptone $20 \mathrm{~g} / \mathrm{L}$; glucose $20 \mathrm{~g} / \mathrm{L} ; \mathrm{pH} 7.2$ ), respectively for $24 \mathrm{~h}$ in $37^{\circ} \mathrm{C}$.

The antagonistic activity was investigated according to the agar well diffusion method. Lactobacillus sp. $\left(10^{6}\right.$ cells $\left./ \mathrm{mL}\right)$ strains were spread over the entire surface of MRS agar in Petri dishes. After $15 \mathrm{~min}, 5 \mathrm{~mm}$ diameter holes were cut from the MRS medium with a cork borer and a volume of $100 \mu \mathrm{L}$ of Viburnum opulus FJ and PJ samples (at concentration of phenolic compounds equal to $11 \mathrm{mg} / \mathrm{mL}$ ) were introduced into the well in triplicate. The cultures were incubated at $37^{\circ} \mathrm{C}$ for $24 \mathrm{~h}$. The same procedure was applied to pathogens with the appropriate abovementioned agar media. Following the incubation, the diameter of the V. opulus sample on the growth inhibition zone was measured, the hole diameter was subtracted and the results were given in $\mathrm{mm}$.

\subsection{VEGF secretion}

Human umbilical endothelial cells (HUVEC) were grown in RPMI medium supplemented with $20 \%$ fetal bovine serum (FBS), $150 \mu \mathrm{g} / \mathrm{mL}$ endothelial growth factor, $100 \mathrm{U} / \mathrm{mL}$ penicillin, $100 \mu \mathrm{g} / \mathrm{mL}$ streptomycin and $25 \mu \mathrm{g} / \mathrm{mL}$ amphotericin B. For the VEGF secretion experiments, the cells were plated in 96-well plates at $5 \times 10^{3}$ cells per well and cultured for $24 \mathrm{~h}$ in standard culture medium. The medium was changed to starving conditions for an additional $24 \mathrm{~h}$ and $V$. opulus samples were added for another $48 \mathrm{~h}$. Culture supernatants were collected and VEGF levels were determined by the VEGF Human ELISA Kit (Life Technologies, Carlsbad, CA, USA), according to the manufacturer's instructions. 


\subsection{Statistical Analysis}

All the biological results are presented as means \pm SEM, $n \geq 4$. All calculations were evaluated for significance using one-way ANOVA, followed by Dunnett's test with GraphPad Prism 6.0 software (GraphPad Software, Inc., La Jolla, CA, USA) at the significance level of ${ }^{*} p \leq 0.05,{ }^{* *} p \leq 0.01$, *** $p \leq 0.001$.

\section{Conclusions}

This is the first study demonstrating the influence of $V$. opulus juice on osteosarcoma Saos-2 cell activity, as shown in Figure 11. As it was observed, fresh juice and purified juice were able to stimulate the mineralization of Saos- 2 cells. Whereas the PJ preparation contained almost 90-times more phenolic compounds than fresh juice, its effective concentration was only 2.5-times lower than fresh juice. Because the composition of FJ and PJ is very complex (more than 30 phenolic compounds were identified) it would be premature to infer that the observed osteogenic potential reported here results only from the main components present in preparations, such as chlorogenic acid, procyanidins or catechins. Moreover, the detected V. opulus fresh juice biological impact might be related to the presence of other non-phenolic compounds, such as sugars, proteins, organic acids, minerals, or other phenolics, which were lost during solid-phase extraction and not detected in PJ. In this regard, potential synergetic activities and chemical interactions may be responsible for the observed cellular effect.

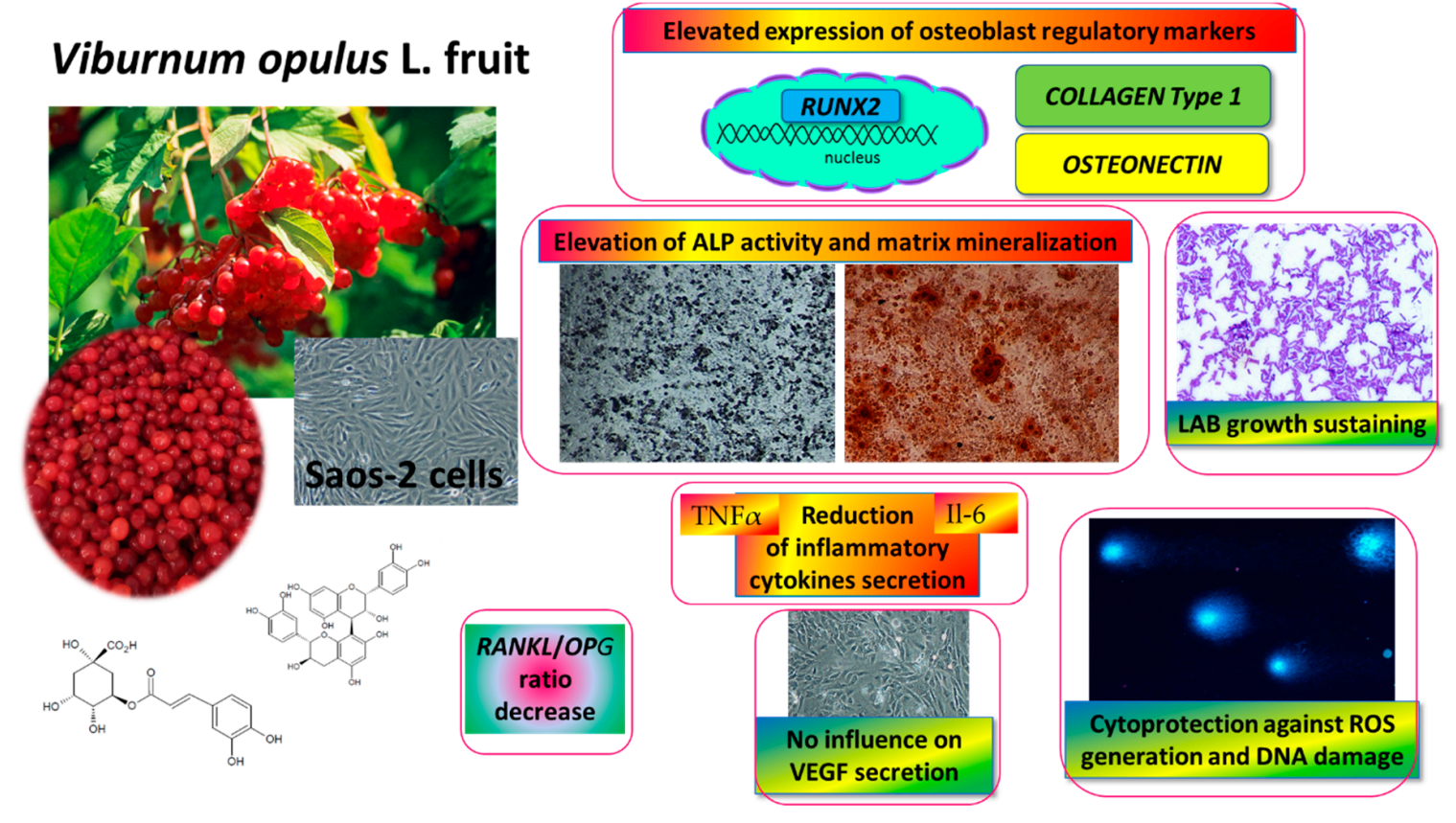

Figure 11. V. opulus fruit juice phenolic compounds as regulators of Saos-2 cell activity-proposed mechanism of action. $V$. opulus upregulates the mineralization of Saos-2 cells with an increase in the expression of the RUNX2 transcription factor; diminishes the release of TNF $\alpha$ and Il6 inflammatory cytokines; possesses cytoprotective activity against ROS generation and DNA damage; sustains lactic acid beneficial microorganism growth.

Both $V$. opulus fruit samples stimulated Saos-2 mineralization via the regulation of the expression of the major osteogenic factor, RUNX2. The main osteogenic differentiation markers, such as ALP, collagen type 1 and osteonectin, were elevated at transcription level. The observed decrease in the $R A N K L / O P G$ ratio may suggest the anti-resorptive ability of $V$. opulus fruits. Furthermore, the secretion of pro-inflammatory cytokines Il6 and $\mathrm{TNF} \alpha$, as well as intracellular oxidative stress, were diminished after cell incubation with samples. These observations reflect the potential of $V$. opulus fruit phenolics to 
decrease bone tissue demineralization, which may be induced by association with obesity inflammation and elevated ROS generation. What is more, V. opulus juice revealed protective properties against cellular damage by the stimulation of DNA repair. Because the release of VEGF protein by HUVEC cells was not affected by the samples, thus we can conclude that no disturbance of the angiogenesis process improves bone tissue formation or regeneration. The ability of $V$. opulus fruit juice phenolic compounds to inhibit pathogenic bacteria without the inhibition of lactic acid-beneficial microorganisms was also demonstrated.

Taken together, our results contribute to elucidate the fact that $V$. opulus fruit juice's molecular mechanism in Saos- 2 cell mineralization process suggests its usage as a diet component potentiating bone health. Still, there is further need to check its osteogenic potential after in vitro digestion or incubation with gut microflora, as well as during in vivo studies with animal models with osteoporosis and induced obesity.

Author Contributions: M.Z.-S. performed cellular in vitro investigation conception, design, study, analysis, visualization, prepared and edited the manuscript. A.N. carried out DNA repair and antimicrobial activity analysis. N.P. performed V. opulus phenolics characterization. A.P. was involved in V. opulus phenolics characterization and funding acquisition. All authors have read and agreed to the published version of the manuscript.

Funding: This research was supported by grant nr 2016/23/B/NZ9/03629 from The National Science Centre, Poland.

Acknowledgments: Małgorzata Zakłos-Szyda gratefully acknowledges Grażyna Budryn and Maria Koziołkiewicz for their encouragement for opening new research possibilities, inspirational ideas and critical comments.

Conflicts of Interest: The authors declare no conflict of interest.

\section{Abbreviations}

$\begin{array}{ll}\text { ALP } & \text { alkaline phosphatase } \\ \text { FJ } & \text { fresh juice } \\ \text { Il6 } & \text { interleukin } 6 \\ \text { NF-kB } & \text { nuclear factor kappa B } \\ \text { OPG } & \text { osteoprotegerin } \\ \text { RANKL } & \text { receptor activator of nuclear factor kappa-B ligand } \\ \text { RUNX2 } & \text { Runt-related transcription factor } 2 \\ \text { ROS } & \text { reactive oxygen species } \\ \text { TNF } \alpha & \text { tumor necrosis factor } \alpha \\ \text { VEGF } & \text { vascular endothelial growth factor } \\ \text { PJ } & \text { purified juice }\end{array}$

\section{References}

1. Domazetovic, V.; Marcucci, G.; Iantomasi, T.; Brandi, M.L.; Vincenzini, M.T. Oxidative stress in bone remodeling: Role of antioxidants. Clin. Cases Miner. Bone Metab. 2017, 14, 209-216. [CrossRef] [PubMed]

2. Nicolin, V.; De Tommasi, N.; Nori, S.L.; Costantinides, F.; Berton, F.; Di Lenarda, R. Modulatory effects of plant polyphenols on bone remodeling: A prospective view from the bench to bedside. Front. Endocrinol. 2019, 10, 494. [CrossRef]

3. Mukudai, Y.; Kondo, S.; Koyama, T.; Li, C.; Banka, S.; Kogure, A.; Yazawa, K. Potential anti-osteoporotic effects of herbal extracts on osteoclasts, osteoblasts and chondrocytes in vitro. BMC Complement. Altern. Med. 2014, 14, 1-14. [CrossRef]

4. Al Anouti, F.; Taha, Z.; Shamim, S.; Khalaf, K.; Al Kaabi, L.; Alsafar, H. An insight into the paradigms of osteoporosis: From genetics to biomechanics. Bone Rep. 2019, 11, 100216. [CrossRef]

5. Komori, T. Regulation of proliferation, differentiation and functions of osteoblasts by runx2. Int. J. Mol. Sci. 2019, 20, 1694. [CrossRef]

6. Zhu, Y.-S.; Gu, Y.; Jiang, C.; Chen, L. Osteonectin regulates the extracellular matrix mineralization of osteoblasts through P38 signaling pathway. J. Cell. Physiol. 2020, 235, 2220-2231. [CrossRef]

7. Park, J.H.; Lee, N.K.; Lee, S.Y. Current understanding of RANK signaling in osteoclast differentiation and maturation. Mol. Cells 2017, 40, 706-713. 
8. Shu, L.; Beier, E.; Sheu, T.; Zhang, H.; Zuscik, M.; Puzas, J.E.; Boyce, F.B.; Mooney, R.; Xing, L. High-fat diet causes bone loss in young mice by promoting osteoclastogenesis through alteration of the bone marrow environment. Calcif. Tissue Int. 2015, 96, 313-323. [CrossRef] [PubMed]

9. Cao, J.J. Effects of obesity on bone metabolism. J. Orthop. Surg. Res. 2011, 6, 30. [CrossRef] [PubMed]

10. Corbo, F.; Brunetti, G.; Crupi, P.; Bortolotti, S.; Storlino, G.; Piacente, L.; Carocci, A.; Catalano, A.; Milani, G.; Colaianni, G.; et al. Effects of sweet cherry polyphenols on enhanced osteoclastogenesis associated with childhood obesity. Front. Immunol. 2019, 10, 1001. [CrossRef]

11. Kyung, T.-W.; Lee, J.-E.; Van Phan, T.; Yu, R.; Choi, H.-S. Osteoclastogenesis by bone marrow-derived macrophages is enhanced in obese mice. J. Nutr. 2009, 139, 502-506. [CrossRef]

12. Wu, Y.; Cao, L.; Xia, L.; Wu, Q.; Wang, J.; Wang, X.; Xu, L.; Zhou, Y.; Xu, Y.; Jiang, X. Evaluation of osteogenesis and angiogenesis of icariin in local controlled release and systemic delivery for calvarial defect in ovariectomized rats. Sci. Rep. 2017, 7, 1-14. [CrossRef] [PubMed]

13. WHO. Library Global Report on Diabetes; WHO Press: Geneva, Switzerland, 2016; Volume 978, pp. 6-86, ISBN 978-92-4-156525-7.

14. Chiva-Blanch, G.; Badimon, L. Effects of polyphenol intake on metabolic syndrome: Current evidences from human trials. Oxid. Med. Cell. Longev. 2017, 2017, 5812401. [CrossRef]

15. Bozzetto, L.; Annuzzi, G.; Pacini, G.; Costabile, G.; Vetrani, C.; Vitale, M.; Griffo, E.; Giacco, A.; De Natale, C.; Cocozza, S.; et al. Polyphenol-rich diets improve glucose metabolism in people at high cardiometabolic risk: A controlled randomised intervention trial. Diabetologia 2015, 58, 1551-1560. [CrossRef]

16. Sequeira, I.R.; Poppitt, S.D. Unfolding novel mechanisms of polyphenol flavonoids for better glycaemic control: Targeting pancreatic islet amyloid polypeptide (IAPP). Nutrients 2017, 9, 788. [CrossRef] [PubMed]

17. Mihaylova, D.; Popova, A.; Alexieva, I.; Krastanov, A.; Lante, A. Polyphenols as Suitable Control for Obesity and Diabetes. Open Biotechnol. J. 2018, 12, 219-228. [CrossRef]

18. Torre, E. Molecular signaling mechanisms behind polyphenol-induced bone anabolism. Phytochem. Rev. 2017, 16, 1183-1226. [CrossRef]

19. Kang, G.G.; Francis, N.; Hill, R.; Waters, D.; Blanchard, C.; Santhakumar, A.B. Dietary polyphenols and gene expression in molecular pathways associated with type 2 diabetes mellitus: A review. Int. J. Mol. Sci. 2020, 21, 140. [CrossRef]

20. Austermann, K.; Baecker, N.; Stehle, P.; Heer, M. Putative effects of nutritive polyphenols on bone metabolism in vivo-Evidence from human studies. Nutrients 2019, 11, 871. [CrossRef]

21. Zheng, X.; Lee, S.K.; Chun, O.K. Soy isoflavones and osteoporotic bone loss: A review with an emphasis on modulation of bone remodeling. J. Med. Food 2016, 19, 1-14. [CrossRef]

22. Zakłos-Szyda, M.; Budryn, G.; Grzelczyk, J.; Perez-Sanchez, H.; Żyżelewicz, D. Evaluation of Isoflavones as bone resorption inhibitors upon interactions with receptor activator of nuclear factor-kb ligand (RANKL). Molecules 2020, 25, 206. [CrossRef]

23. Torre, E.; Iviglia, G.; Cassinelli, C.; Morra, M.; Russo, N. Polyphenols from grape pomace induce osteogenic differentiation in mesenchymal stem cells. Int. J. Mol. Med. 2020, 45, 1721-1734. [CrossRef]

24. Zakłos-Szyda, M.; Pawlik, N.; Polka, D.; Nowak, A.; Koziołkiewicz, M.; Podsędek, A. Viburnum opulus fruit phenolic compounds as cytoprotective agents able to decrease free fatty acids and glucose uptake by Caco-2 cells. Antioxidants 2019, 8, 262. [CrossRef]

25. Zakłos-Szyda, M.; Majewska, I.; Redzynia, M.; Koziołkiewicz, M. Antidiabetic effect of polyphenolic extracts from selected edible plants as $\alpha$-amylase, $\alpha$-glucosidase and PTP1B inhibitors, and $\beta$ pancreatic cells cytoprotective agents-A comparative study. Curr. Top. Med. Chem. 2015, 15, 2431-2444. [CrossRef]

26. Zakłos-Szyda, M.; Pawlik, N. The influence of Viburnum opulus polyphenolic compounds on metabolic activity and migration of HeLa and MCF cells. Acta Innov. 2019, 33, 33-42. [CrossRef]

27. Act, J.O.P.; Ruosi, C.; Querques, F.; Granata, F.; Colella, G.; Liccardo, S.; Lombardo, B.; Pastore, L. Cellular and animal models for the identification of osteoporosis determinants increasing vertebral compression fractures risk. Osteoporos. Phys. Act. 2015, 3, 2.

28. Česoniene, L.; Daubaras, R.; Vencloviene, J.; Viškelis, P. Biochemical and agro-biological diversity of Viburnum opulus genotypes. Cent. Eur. J. Biol. 2010, 5, 864-871. [CrossRef]

29. Zakłos, M.; Pietrzyk, N.; Szustak, M.; Podsędek, A. Viburnum opulus L. juice phenolics inhibit mouse 3T3-L1 cells adipogenesis and pancreatic lipase activity. Nutrients 2020, 12, 2003. [CrossRef] 
30. Zakłos-Szyda, M.; Kowalska-Baron, A.; Pietrzyk, N.; Drzazga, A. Evaluation of Viburnum opulus L. fruit phenolics cytoprotective potential on insulinoma MIN6 cells relevant for diabetes mellitus and obesity. Antioxidants 2020, 9, 433. [CrossRef]

31. Min, J.; Yuan, Z.; Zhang, Q.; Lin, S.; Wang, K.; Luo, J. Analysis of anti-osteoporosis function of chlorogenic acid by gene microarray profiling in ovariectomy rat model. Biosci. Rep. 2018, 38. [CrossRef]

32. Perova, I.B.; Zhogova, A.A.; Cherkashin, A.V.; Éller, K.I.; Ramenskaya, G.V. Biologically active substances from european guelder berry fruits. Pharm. Chem. J. 2014, 48, 332-339. [CrossRef]

33. Ghiacci, G.; Lumetti, S.; Mori, D.; Macaluso, G.M.; Sala, R. Stanozolol promotes osteogenic gene expression and apposition of bone mineral in vitro Abstract. J. Appl. Oral Serv. 2019, 27, e20180014.

34. Prideaux, M.; Wijenayaka, A.R.; Kumarasinghe, D.D.; Ormsby, R.T.; Evdokiou, A.; Findlay, D.M.; Atkins, G.J. SaOS2 osteosarcoma cells as an in vitro model for studying the transition of human osteoblasts to osteocytes. Calcif. Tissue Int. 2014, 95, 183-193. [CrossRef]

35. Graef, J.L.; Rendina-ruedy, E.; Crockett, E.K.; Ouyang, P.; Jarrod, B.; Cichewicz, R.H.; Lucas, E.A.; Smith, B.J. Select polyphenolic fractions from dried plum enhance osteoblast activity through BMP-2 signaling. J. Nutr. Biochem. 2019, 55, 59-67. [CrossRef]

36. Bin, H.S.; Jeong, J.H.; Choi, U.K. Chlorogenic acid promotes osteoblastogenesis in human adipose tissue-derived mesenchymal stem cells. Food Sci. Biotechnol. 2013, 22, 107-112. [CrossRef]

37. Kim, B.; Lee, S.; Song, S.; Kim, W.H.; Song, E.; Lee, J.; Lee, S.; Han, D.; Lee, J. Protective effects of melon extracts on bone strength, mineralization, and metabolism in rats with ovariectomy-induced osteoporosis. Antioxidants 2019, 8, 306. [CrossRef] [PubMed]

38. Zhou, R.P.; Lin, S.J.; Wan, W.B.; Zuo, H.L.; Yao, F.F.; Ruan, H.B.; Xu, J.; Song, W.; Zhou, Y.C.; Wen, S.Y.; et al. Chlorogenic acid prevents osteoporosis by Shp2/PI3K/Akt pathway in ovariectomized rats. PLoS ONE 2016, 11, e0166751. [CrossRef]

39. Byun, M.R.; Sung, M.K.; Kim, A.R.; Lee, C.H.; Jang, E.J.; Jeong, M.G.; Noh, M.; Hwang, E.S.; Hong, J.H. (-)-Epicatechin gallate (ECG) stimulates osteoblast differentiation via runt-related transcription factor 2 (RUNX2) and transcriptional coactivator with PDZ-binding motif (TAZ)-mediated transcriptional activation. J. Biol. Chem. 2014, 289, 9926-9935. [CrossRef]

40. Kovar, H.; Bierbaumer, L.; Radic-sarikas, B. The YAP/TAZ pathway in osteogenesis and bone sarcoma pathogenesis. Cells 2020, 9, 972. [CrossRef]

41. El Ouarrat, D.; Isaac, R.; Lee, Y.S.; Oh, D.Y.; Wollam, J.; Lackey, D.; Riopel, M.; Bandyopadhyay, G.; Seo, J.B.; Sampath-Kumar, R.; et al. TAZ is a negative regulator of PPAR $\gamma$ activity in adipocytes and TAZ deletion improves insulin sensitivity and glucose tolerance. Cell Metab. 2020, 31, 162-173.e5. [CrossRef]

42. Lin, S.Y.; Kang, L.; Wang, C.Z.; Huang, H.H.; Cheng, T.L.; Huang, H.T.; Lee, M.J.; Lin, Y.S.; Ho, M.L.; Wang, G.J.; et al. (-)-Epigallocatechin-3-gallate (EGCG) enhances osteogenic differentiation of human bone marrow mesenchymal stem cells. Molecules 2018, 23, 3221. [CrossRef]

43. Feng, X.; Teitelbaum, S.L. Osteoclasts: New Insights. Bone Research 2013, 1, 11-26.

44. Shin, J.; Kim, J.E.; Pak, K.J.; Kang, J.I.; Kim, T.S.; Lee, S.Y.; Yeo, I.H.; Park, J.H.Y.; Kim, J.H.; Kang, N.J.; et al. A combination of soybean and Haematococcus extract alleviates ultraviolet B-induced photoaging. Int. J. Mol. Sci. 2017, 18, 682. [CrossRef]

45. Chen, S.T.; Kang, L.; Wang, C.Z.; Huang, P.J.; Huang, H.T.; Lin, S.Y.; Chou, S.H.; Lu, C.C.; Shen, P.C.; Lin, Y.S.; et al. (-)-Epigallocatechin-3-gallate decreases osteoclastogenesis via modulation of RANKL and osteoprotegrin. Molecules 2019, 24, 156. [CrossRef]

46. Kwak, S.C.; Lee, C.; Kim, J.Y.; Oh, H.M.; So, H.S.; Lee, M.S.; Rho, M.C.; Oh, J. Chlorogenic acid inhibits osteoclast differentiation and bone resorption by down-regulation of receptor activator of nuclear factor kappa-b ligand-induced nuclear factor of activated t cells c1 expression. Biol. Pharm. Bull. 2013, 36, 1779-1786. [CrossRef] [PubMed]

47. Sungkamanee, S.; Wattanathorn, J.; Muchimapura, S.; Thukham-Mee, W. Antiosteoporotic effect of combined extract of morus alba and polygonum odoratum. Oxid. Med. Cell. Longev. 2014, 2014, 579305. [CrossRef]

48. Jia, M.; Nie, Y.; Cao, D.P.; Xue, Y.Y.; Wang, J.S.; Zhao, L.; Rahman, K.; Zhang, Q.Y.; Qin, L.P. Potential antiosteoporotic agents from plants: A comprehensive review. Evid.-Based Complement. Altern. Med. 2012, 2012, 364604. [CrossRef] 
49. Bai, X.C.; Lu, D.; Bai, J.; Zheng, H.; Ke, Z.Y.; Li, X.M.; Luo, S.Q. Oxidative stress inhibits osteoblastic differentiation of bone cells by ERK and NF-кB. Biochem. Biophys. Res. Commun. 2004, 314, 197-207. [CrossRef]

50. Zhang, Z.; Zheng, L.; Zhao, Z.; Shi, J.; Wang, X.; Huang, J. Grape seed proanthocyanidins inhibit $\mathrm{H}_{2} \mathrm{O}_{2}$-induced osteoblastic MC3T3-E1 cell apoptosis via ameliorating $\mathrm{H}_{2} \mathrm{O}_{2}$-induced mitochondrial dysfunction. J. Toxicol. Sci. 2014, 39, 803-813. [CrossRef]

51. Su, S.; Yeh, Y.; Shyu, H. The Preventive effect of biochanin a on bone loss in ovariectomized rats: Involvement in regulation of growth and activity of osteoblasts and osteoclasts. Evid.-Based Complement. Altern. Med. 2013, 2013, 1-10.

52. Nash, L.A.; Ward, W.E. Comparison of black, green and rooibos tea on osteoblast activity. Food Funct. 2016, 7, 1166-1175. [CrossRef] [PubMed]

53. Shapses Sue, A.; Claudia, P.; Wang, Y. Obesity is a concern for bone health with aging. Nutr. Res. 2017, 39, 1-13. [CrossRef] [PubMed]

54. Liang, N.; Kitts, D.D. Role of chlorogenic acids in controlling oxidative and inflammatory stress conditions. Nutrients 2016, 8, 16. [CrossRef]

55. Stegen, S.; van Gastel, N.; Carmeliet, G. Bringing new life to damaged bone: The importance of angiogenesis in bone repair and regeneration. Bone 2015, 70, 19-27. [CrossRef]

56. Park, J.J.; Hwang, S.J.; Park, J.H.; Lee, H.J. Chlorogenic acid inhibits hypoxia-induced angiogenesis via down-regulation of the HIF-1 $\alpha /$ AKT pathway. Cell. Oncol. 2015, 38, 111-118. [CrossRef] [PubMed]

57. Ana, C.; Mark, W.; Christina, M.; Paul, N.; Kroon, P.A. Molecular structure-function relationship of dietary polyphenols for inhibiting VEGF-induced VEGFR-2 activity. Mol. Nutr. Food Res. 2015, 59, $2119-2131$.

58. Tsakiroglou, P.; Weber, J.; Ashworth, S.; Del Bo, C.; Klimis-Zacas, D. Phenolic and anthocyanin fractions from wild blueberries ( $V$. angustifolium) differentially modulate endothelial cell migration partially through RHOA and RAC1. J. Cell. Biochem. 2019, 120, 11056-11067. [CrossRef] [PubMed]

59. Wang, A.; Leong, D.J.; He, Z.; Xu, L.; Liu, L.; Kim, S.J.; Hirsh, D.M.; Hardin, J.A.; Cobelli, N.J.; Sun, H.B. Procyanidins mitigate osteoarthritis pathogenesis by, at least in part, suppressing vascular endothelial growth factor signaling. Int. J. Mol. Sci. 2016, 17, 2065. [CrossRef]

60. Farah, A.; dePaula Lima, J. Consumption of chlorogenic acids through coffee and health implications. Beverages 2019, 5, 11. [CrossRef]

61. Farah, A.; Monteiro, M.; Donangelo, C.M.; Lafay, S. Chlorogenic Acids from Green Coffee Extract are Highly Bioavailable in Humans. J. Nutr. 2008, 138, 2309-2315. [CrossRef]

62. Clifford, M.N.; Kerimi, A.; Williamson, G. Bioavailability and metabolism of chlorogenic acids (acyl-quinic acids) in humans. Compr. Rev. Food Sci. Food Saf. 2020, 1-54. [CrossRef]

63. Gwiazdowska, D.; Juś, K.; Jasnowska-Małecka, J.; Kluczyńska, K. The impact of polyphenols on Bifidobacterium growth. Acta Biochim. Pol. 2015, 62, 895-901. [CrossRef] [PubMed]

64. Bouarab-Chibane, L.; Forquet, V.; Lantéri, P.; Clément, Y.; Léonard-Akkari, L.; Oulahal, N.; Degraeve, P.; Bordes, C. Antibacterial properties of polyphenols: Characterization and QSAR (Quantitative structure-activity relationship) models. Front. Microbiol. 2019, 10, 829. [CrossRef] [PubMed]

65. Unusan, N. Proanthocyanidins in grape seeds: An updated review of their health benefits and potential uses in the food industry. J. Funct. Foods 2020, 67, 103861. [CrossRef]

66. Naveed, M.; Hejazi, V.; Abbas, M.; Kamboh, A.A.; Khan, G.J.; Shumzaid, M.; Ahmad, F.; Babazadeh, D.; FangFang, X.; Modarresi-Ghazani, F.; et al. Chlorogenic acid (CGA): A pharmacological review and call for further research. Biomed. Pharmacother. 2018, 97, 67-74. [CrossRef]

67. George Kerry, R.; Patra, J.K.; Gouda, S.; Park, Y.; Shin, H.S.; Das, G. Benefaction of probiotics for human health: A review. J. Food Drug Anal. 2018, 26, 927-939. [CrossRef]

68. Wang, Z.; Hu, K.L.J.; Ge, S.; Zhou, A.; Zheng, B.; Zeng, S.; Lin, S. Chlorogenic acid alleviates obesity and modulates gut microbiota in high-fed mice. Food Sci. Nutr. 2019, 7, 579-588. [CrossRef]

69. Yan, J.; Takakura, A.; Zandi-Nejad, K.; Charles, J.F. Mechanisms of gut microbiota-mediated bone remodeling. Gut Microbes 2018, 9, 84-92. [CrossRef]

70. Gilman, J.; Cashman, K.D. The effect of probiotic bacteria on transepithelial calcium transport and calcium uptake in human intestinal-like caco-2 cells. Curr. Issues Intest. Microbiol. 2006, 7, 1-6. 
71. Gatej, S.M.; Marino, V.; Bright, R.; Fitzsimmons, T.R.; Gully, N.; Zilm, P.; Gibson, R.J.; Edwards, S.; Bartold, P.M. Probiotic Lactobacillus rhamnosus GG prevents alveolar bone loss in a mouse model of experimental periodontitis. J. Clin. Periodontol. 2018, 45, 204-212. [CrossRef]

72. Xu, X.; Jia, X.; Mo, L.; Liu, C.; Zheng, L.; Yuan, Q.; Zhou, X. Intestinal microbiota: A potential target for the treatment of postmenopausal osteoporosis. Bone Res. 2017, 5, 1-18. [CrossRef] [PubMed]

73. Das, M.; Cronin, O.; Keohane, D.M.; Cormac, E.M.; Nugent, H.; Nugent, M.; Molloy, C.; O'toole, P.W.; Shanahan, F.; Molloy, M.G.; et al. Gut microbiota alterations associated with reduced bone mineral density in older adults. Rheumatol. 2019, 58, 2295-2304. [CrossRef] [PubMed]

74. Li, L.; Rao, S.; Cheng, Y.; Zhuo, X.; Deng, C.; Xu, N.; Zhang, H.; Yang, L. Microbial osteoporosis: The interplay between the gut microbiota and bones via host metabolism and immunity. Microbiologyopen 2019, 8, e00810. [CrossRef]

75. Nowak, A.; Śliżewska, K.; Otlewska, A. Antigenotoxic activity of lactic acid bacteria, prebiotics, and products of their fermentation against selected mutagens. Regul. Toxicol. Pharmacol. 2015, 73, 938-946. [CrossRef]

76. Muthusami, S.; Senthilkumar, K.; Vignesh, C.; Ilangovan, R.; Stanley, J.; Selvamurugan, N.; Srinivasan, N. Effects of Cissus quadrangularis on the Proliferation, differentiation and matrix mineralization of human osteoblast like SaOS-2 Cells. J. Cell. Biochem. 2011, 1045, 1035-1045. [CrossRef]

(C) 2020 by the authors. Licensee MDPI, Basel, Switzerland. This article is an open access article distributed under the terms and conditions of the Creative Commons Attribution (CC BY) license (http://creativecommons.org/licenses/by/4.0/). 